\title{
Isoprene suppression of new particle formation in a mixed deciduous forest
}

\author{
V. P. Kanawade ${ }^{1}$, B. T. Jobson ${ }^{2}$, A. B. Guenther ${ }^{3}$, M. E. Erupe ${ }^{1}$, S. N. Pressley ${ }^{2}$, S. N. Tripathi ${ }^{4}$, and S.-H. Lee ${ }^{1}$ \\ ${ }^{1}$ Department of Chemistry and Biochemistry, Kent State University, Kent, OH 44242, USA \\ ${ }^{2}$ Department of Civil and Environmental Engineering, Washington State University, WA 99164, USA \\ ${ }^{3}$ National Center for Atmospheric Research, Atmospheric Chemistry Division, Boulder, CO 80307, USA \\ ${ }^{4}$ Department of Civil Engineering and Center for Environmental Engineering and Science, Indian Institute of Technology, \\ Kanpur 208016, Uttar Pradesh, India
}

Received: 19 March 2011 - Published in Atmos. Chem. Phys. Discuss.: 8 April 2011

Revised: 13 June 2011 - Accepted: 20 June 2011 - Published: 24 June 2011

\begin{abstract}
Production of new particles over forests is an important source of cloud condensation nuclei that can affect climate. While such particle formation events have been widely observed, their formation mechanisms over forests are poorly understood. Our observations made in a mixed deciduous forest with large isoprene emissions during the summer displayed a surprisingly rare occurrence of new particle formation (NPF). Typically, NPF events occur around noon but no NPF events were observed during the 5 weeks of measurements. The exceptions were two evening ultrafine particle events. During the day, sulfuric acid concentrations were in the $10^{6} \mathrm{~cm}^{-3}$ range with very low preexisting aerosol particles, a favorable condition for NPF to occur even during the summer. The ratio of emitted isoprene carbon to monoterpene carbon at this site was similar to that in Amazon rainforests (ratio $>10$ ), where NPF events are also very rare, compared with a ratio $<0.5$ in Finland boreal forests, where NPF events are frequent. Our results suggest that large isoprene emissions can suppress NPF formation in forests although the underlying mechanism for the suppression is unclear. The two evening ultrafine particle events were associated with the transported anthropogenic sulfur plumes and ultrafine particles were likely formed via ion-induced nucleation. Changes in landcover and environmental conditions could modify the isoprene suppression of NPF in some forest regions resulting in a radiative forcing that could have influence on the climate.
\end{abstract}

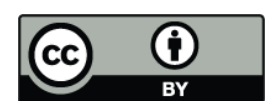

Correspondence to: V. P. Kanawade (vkanawad@kent.edu)

\section{Introduction}

While having a large impact on regional climate, aerosol particles also affect human health, air quality and visibility. Particle nucleation (formation of a liquid or solid particle from gas phase species) occurs nearly everywhere in the Earth's atmosphere (Kulmala et al., 2004) and these newly formed particles contribute $15-55 \%$ of the global cloud condensation nuclei (CCN) production (Spracklen et al., 2008). CCN production rates and the impact of anthropogenic and natural emissions on these rates are crucial for quantifying aerosol indirect effects on the radiative forcing of climate. New particle formation (NPF) events also have a distinctive seasonal variation globally, with the higher frequency in spring and fall $(\sim 30-50 \%)$ and the lower frequency in summer and winter $(\sim 10-15 \%)$ (Kulmala et al., 2004). Observations show that sulfuric acid $\left(\mathrm{H}_{2} \mathrm{SO}_{4}\right)$ (Kuang et al., 2008; Sipila et al., 2010; Vehkamäki et al., 2002) is the main particle nucleation precursor. However, ammonia $\left(\mathrm{NH}_{3}\right)$ (Ball et al., 1999; Merikanto et al., 2007), organic compounds including amines and organic acids (Hoffmann et al., 1998; Metzger et al., 2010; O'Dowd et al., 2002; Smith et al., 2009; Zhang et al., 2004), and charged ion clusters (Lee et al., 2003; Yu and Turco, 1997; Lovejoy et al., 2004) can also be involved in the particle nucleation under different atmospheric conditions. At present, the processes leading to formation of new particles in various atmospheric environments, especially in the boundary layer, remain unclear.

Forests cover about one-third of the earth's land surface but contribute about two-third of global biogenic volatile organic compound (BVOC) emissions (Goldstein and Galbally, 2007; Guenther et al., 1995). The global emission of

Published by Copernicus Publications on behalf of the European Geosciences Union. 
isoprene, which is the predominant $\mathrm{BVOC}$, is estimated to be 440-600 teragrams of carbon $(\mathrm{TgC}) \mathrm{yr}^{-1}$ (Guenther et al., 2006). The latest estimate of secondary organic aerosol for-

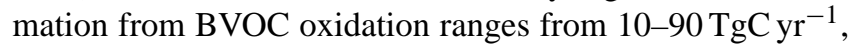
a significantly large fraction of the total organic aerosol budget on a global scale (Hallquist et al., 2009; Heald et al., 2008). There are large uncertainties in these estimates, which are sensitive to the estimation method (e.g., top-down versus bottom-up) and the detailed chemistry of secondary organic aerosol formation (Hallquist et al., 2009).

Field observations and laboratory experiments show that low volatility oxidation products of biogenic monoterpenes (MT) and sequiterpenes (SQT) (e.g., cis-pinonic or cispinic acids, organic peroxides, and criegee intermediate compounds) can contribute to aerosol nucleation (Bonn and Moortgat, 2003; O'Dowd et al., 2002; Hoffmann et al., 1998; Tunved et al., 2006; Burkholder et al., 2007). Isoprene oxidation products can also be important in aerosol growth as observed in laboratory studies (Claeys et al., 2004; Surratt et al., 2010) and field observations (Froyd et al., 2010; Zhang et al., $2009)$, under both low and high nitrogen oxides $\left(\mathrm{NO}_{\mathrm{x}}=\mathrm{NO}\right.$ $+\mathrm{NO}_{2}$ ) conditions. However, a recent study based on plant chamber experiments has suggested that in forests, isoprene emissions could suppress biogenic NPF (Kiendler-Scharr et al., 2009). This suppression would reduce the aerosol climate cooling effects over forests, because increasing temperatures in the northern latitudes would increase isoprene emissions, and reduce NPF rates, causing more solar radiation to reach the surface. However, atmospheric observational evidence of isoprene suppression of NPF in actual forest environments is currently lacking.

NPF has been observed widely in various forest environments, such as Finland boreal forests (Sihto et al., 2006; Makela et al., 1997), European coniferous forests (Held et al., 2004) and African savanna forests (Laakso et al., 2008). In contrast to these forests, NPF has not been reported from Amazonian forests, even though this region has been studied for decades (Martin et al., 2010; Zhou et al., 2002; Pöschl et al., 2010). The exceptions were unique situations, when ultrafine particles formed in the outflow of clouds were transported from the free troposphere down to the boundary layer (Rizzo et al., 2010). In Amazonian forests, the aerosol surface area appears to be too large for active NPF, and low volatility oxidation products of BVOCs were instead scavenged rapidly to the pre-existing aerosol particles.

The forests in northern Michigan are largely composed of bigtooth aspen (Populus grandidentata Michx.), quaking aspen (P. tremuloides Michx.) (two predominant species), beech (Fagus grandifolia Ehrh.), paper birch (Betula papyrifera Marsh.), maple (Acer rubrum L., A. saccharum Marsh.), red oak (Quercus rubra L.), white pine (Pinus strobus L.) and bracken fern (Pteridium aquilium) (Pearsall, $1995)$ and therefore, are representative of a typical northern mid-western United States deciduous forests. Isoprene emissions are particularly large ( $>95 \%$ of the total terpenoid emissions) compared to MT and SQT emissions (Ortega et al., 2007). The mixed deciduous type Michigan forest thus provides an ideal environment to study NPF from BVOCs, as the BVOC emission fluxes, particularly for isoprene, have been systematically studied for more than ten years (Pressley et al., 2005; Apel et al., 2002; Westberg et al., 2001). However, despite intensive studies in the Michigan forest, ultrafine particle measurements have been limited, except one study which showed formation of Aitken mode particles in the size range from $15-40 \mathrm{~nm}$ from breaking waves on Lake Michigan (Slade et al., 2010) and another study showing Aitken mode particle formation associated with intense sulfur plumes (Delia, 2004). Studies from a similar deciduous forest site in the mid-western United States (Indiana) have observed frequent NPF events but the cause of these events was linked to the close proximity of large urban areas, with elevated concentrations of $\mathrm{H}_{2} \mathrm{SO}_{4}$ (in the $10^{7} \mathrm{~cm}^{-3}$ range) and sulfur dioxide $\left(\mathrm{SO}_{2}\right)$ (Pryor et al., 2010).

In this paper, we report a comprehensive study of ultrafine particles in a relatively clean Michigan forest during the summer of 2009. Aerosol particles in the diameter range from 3-109 $\mathrm{nm}$ were measured at the University of Michigan Biological Station (UMBS) at ground level $(5 \mathrm{~m})$ from 1 July-3 August 2009. $\mathrm{H}_{2} \mathrm{SO}_{4}, \mathrm{NH}_{3}, \mathrm{SO}_{2}, \mathrm{NO}_{\mathrm{x}}, \mathrm{OH}$, and various VOCs (including isoprene and MT) were also measured at the same site. We have further calculated isoprene, MT and SQT emission rates with the Model of Emissions of Gases and Aerosols from Nature (MEGAN) model (Guenther et al., 2006). Simulations with a microphysical box model incorporated with ion-induced nucleation (IIN) (Lovejoy et al., 2004) were also performed to investigate the nucleation mechanism responsible for the two early evening ultrafine particle events seen in the Michigan forest. A brief description of the analytical methods is provided in the following section.

\section{Methods}

\subsection{Observation site}

The measurements were made during the Program for Research on Oxidants PHotochemistry, Emissions, and Transport (PROPHET) Community Atmosphere-Biosphere INteractions Experiments (CABINEX)-2009 campaign at the UMBS $\left(45.56^{\circ} \mathrm{N}, 84.72^{\circ} \mathrm{W}\right)$ from 1 July-3 August 2009. A complete description of the measurement site, including weather conditions are reported previously (Cooper et al., 2001, Carroll et al., 2001), and the platform details can be found elsewhere (Steiner et al., 2011, this issue). Figure 1 shows the location of the UMBS measurement site on a regional map, along with point sources ( $>10^{3}$ tons) of $\mathrm{SO}_{2}$ and $\mathrm{NO}_{\mathrm{x}}$ for 2009. The unique feature of this site is that isoprene, MT and SQT have been measured since 1998 (Westberg et al., 2001; Apel et al., 2002; Pressley et al., 2005; Pressley et 


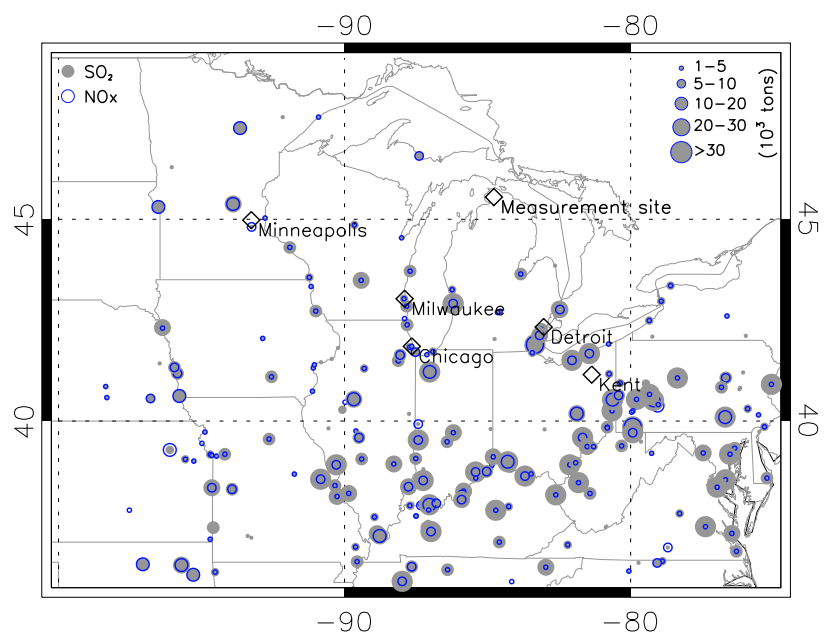

Fig. 1. A regional map showing the location of the Michigan forest measurement site (UMBS) as well as major urban centers (open diamonds), such as Minneapolis, Chicago, and Detroit, in addition to Kent. Both the $\mathrm{SO}_{2}$ (gray dots) and $\mathrm{NO}_{\mathrm{x}}$ (open blue circles) point sources $\left(>10^{3}\right.$ tons) for 2009 are also shown. The size of the dot and circle is proportional to the facility $\mathrm{SO}_{2}$ and $\mathrm{NO}_{\mathrm{x}}$ emission strength. The emissions data are obtained from the US Environmental Protection Agency (EPA) Office of Air and Radiation website (http://www.epa.gov/air/data/geosel.html) under Acid Rain Program.

al., 2006; Barket Jr. et al., 2001; Kim et al., 2009; Ortega et al., 2007). The specific ecosystem at this site is in the transition zone between the mixed hardwood and the boreal forest on a high-outwash plain deposited by glacial drift (Pearsall, 1995; Schmid et al., 2003). The measurement site is heavily forested with minimal interferences of local anthropogenic pollution sources. This site is ideal for studying atmospheric chemistry under a wide range of environmental conditions, including clean continental air from central Canada, mixed air masses of biogenic and anthropogenic influence, and urban plumes from Midwestern industrial centers (Cooper et al., 2001; Carroll et al., 2001).

\subsection{Aerosol and trace gas measurements and trajectory calculations}

Aerosol size distributions were measured with Kent State University's three sets of different scanning mobility particle spectrometers (SMPS). Particle concentrations in the diameter range 3-109 $\mathrm{nm}$ were measured with a nano-differential mobility analyzer (NDMA, TSI 3085) in combination with a water condensation particle counter (CPC, TSI 3786) and in the size range $4-157 \mathrm{~nm}$ with a NDMA (TSI 3085) in combination with a butanol CPC (TSI 3776) at the ground level height $(5 \mathrm{~m})$. Particle concentrations for size range 20-800 nm were measured with a Long-DMA (TSI 3081) in combination with a butanol-CPC (TSI 3772) at a height of $26.6 \mathrm{~m}$, about $6 \mathrm{~m}$ above the height of the canopy. In this analysis, we used $5 \mathrm{~m}$ height data from 1 July-3 August 2009.

$\mathrm{H}_{2} \mathrm{SO}_{4}$ and $\mathrm{NH}_{3}$ were also measured with Kent State University's two chemical ionization mass spectrometers (CIMSs) during the same period (Benson et al., 2008, 2009, 2010, 2011; Erupe et al., 2010; Nowak et al., 2006; Tanner and Eisele, 1995; Young et al., 2008). $\mathrm{H}_{2} \mathrm{SO}_{4}$ was measured using $\mathrm{NO}_{3}^{-}$ions as a reagent. The detection limit of $\mathrm{H}_{2} \mathrm{SO}_{4}$-CIMS was $\sim 2 \times 10^{5} \mathrm{~cm}^{-3}$ and the uncertainty associated with the measurement was estimated to be $\sim 60 \%$ at maximum (Erupe et al., 2010). Protonated ethanol ions were used for $\mathrm{NH}_{3}$ detection. The detection limit of $\mathrm{NH}_{3}-\mathrm{CIMS}$ was $\sim 0.06 \mathrm{ppbv}$ and the overall uncertainty associated with the measurement was $0.03 \mathrm{ppbv} \pm 30 \%$ (Benson et al., 2010).

A variety of volatile organic compounds (VOCs), including isoprene, MT, and isoprene oxidation products [e.g., methylvinylketone (MVK) and methacrolein (MACR)] were measured by Washington State University proton transfer reaction mass spectrometer (PTR-MS) (Lindinger et al., 1998; de Gouw and Warneke, 2007). The PTR-MS instrument uses $\mathrm{H}_{3} \mathrm{O}^{+}$as an reagent ion and the detection limit ranged from 0.01-0.1 pptv (de Gouw and Warneke, 2007). Нydroxyl $(\mathrm{OH})$ radicals were measured by the Indiana University laser induced fluorescence (LIF) instrument (Dusanter et al., 2009); the detection limit was $\sim 2 \times 10^{5} \mathrm{~cm}^{-3}$ with the estimated uncertainty of $\pm 18 \%(1 \sigma)$. Isoprene and speciated MT fluxes were measured by National Center for Atmospheric Research (NCAR) using a cartridge Relaxed Eddy Accumulation (REA) system. Samples were collected on Tenax GR and Carbograph 5TD adsorbent tubes and analyzed with an Agilent 7890A gas chromatograph with a flame ionization detector for quantification and a 5975C electron impact mass spectrometer for identification. $\mathrm{SO}_{2}$ was measured by the University of Houston with a Thermo Environmental 43i-TLE pulsed UV-flourescence analyzer; the detection limit was $0.058-0.095 \mathrm{ppbv}$ with an uncertainty of $\pm 10 \%$. NO and $\mathrm{NO}_{2}$ were measured by Washington State University with a chemiluminescence detector with a measurement accuracy of $7.5 \%$. Meteorological parameters such as air temperature, relative humidity (RH), wind speed, and wind direction were measured by Washington State University with a Vaisala Weather Transmitter (WXT520). All these measurements were made at the ground level height $(\sim 6 \mathrm{~m})$

Backward trajectories of air masses were calculated with the National Oceanic and Atmospheric Administration (NOAA) Air Resources Laboratory (ARL) Hybrid SingleParticle Lagrangian Integrated Trajectory (HYSPLIT) PC version model (.)(Draxler and Rolph, 2010) using gridded wind fields from the Eta Data Assimilation System (EDAS) (Kanamitsu, 1989). 


\subsection{SCIAMACHY $\mathrm{NO}_{2}$ column retrievals}

The SCanning Imaging Absorption spectroMeter for Atmospheric CartograpHY (SCIAMACHY) instrument was launched on the European ENVIronmental SATellite (ENVISAT) spacecraft in March 2002 in a sun-synchronous orbit at an altitude of $800 \mathrm{~km}$ (Bovensmann et al., 1999). The instrument measures backscattered solar radiation in the ultraviolet, visible, and near-infrared regions of the spectrum, from $0.24-2.38 \mu \mathrm{m}$, in the nadir and limb modes. In the nadir mode the horizontal resolution is $30 \mathrm{~km} \times 60 \mathrm{~km}$, and the instrument achieves global observational coverage within 6 days. In the present study, we used retrievals of the tropospheric column abundance of $\mathrm{NO}_{2}$ using the Differential Optical Absorption Spectroscopy (DOAS) algorithm (Richter et al., 2005) to locate large point sources of anthropogenic emissions in the regional vicinity of the UMBS measurement site.

\subsection{Model of emissions of gases and aerosols from nature}

Emissions rates of isoprene, MT and SQT were estimated using the MEGAN model, version 2.04 (Guenther et al., 2006; Sakulyanontvittaya et al., 2008). MEGAN is a global model with a base resolution of $\sim 1 \mathrm{~km}$ that estimates the net emission rates of biogenic VOCs and aerosols such as fungal spores and pollen, from terrestrial ecosystems into the atmosphere. A site-specific version of MEGAN was used to simulate biogenic VOC emissions during the CABINEX campaign, using site-specific emission factors, landcover and weather conditions. Isoprene and MT emission factors (mg compound $\mathrm{m}^{-2}$ ground area $\mathrm{h}^{-1}$ ) were based on the REA flux measurements conducted during the CABINEX while SQT fluxes, which were not measured during the CABINEX, were based on earlier observations at this site reported by Kim et al. (Kim et al., 2009). Individual MT and SQT species were classified as light dependent, light-independent, or fractions of both based on the observations of Ortega et al. (Ortega et al., 2007) at this site. Thirty-minute average variations in emissions estimated with MEGAN were driven by changes in landcover data and environmental conditions. Landcover inputs consisted of monthly average Leaf Area Index (LAI) based on ground-based data for this site. LAI variations were used to characterize changes in total foliage and leaf age according to procedures described by Guenther et al. (Guenther et al., 2006). Other inputs to MEGAN included temperature and photosynthetic active radiation measured at this site above the canopy. Leaf temperature and sun and shade fractions were calculated at five canopy depths and used to drive the short-term and long-term components of the Guenther et al. (2006) algorithm for simulating the emission response to light and temperature.

\subsection{Aerosol microphysical box model incorporated with IIN parameterization}

The sulfuric acid-water aerosol microphysical ion nucleation (SAMIN) box model (Kanawade and Tripathi, 2006) was used in our nucleation simulations. SAMIN includes the IIN parameterization (Modgil et al., 2005) which was based on the IIN kinetic model (Lovejoy et al., 2004). The IIN model uses the laboratory measured thermodynamic data for the growth and evaporation of small cluster ions containing $\mathrm{H}_{2} \mathrm{SO}_{4}$ and $\mathrm{H}_{2} \mathrm{O}$ (Lovejoy et al., 2004) and has been constrained by in-situ measurements of aerosol sizes and precursors at a wide range of atmospheric conditions (Lee et al., 2003). Positive ions are less likely to nucleate compared to negative ions (Froyd and Lovejoy, 2003), and the IIN kinetic model treats positive ions as a single species and treats the neutral and negative ions explicitly (Lovejoy et al., 2004). SAMIN simulates IIN parameterization, $\mathrm{H}_{2} \mathrm{SO}_{4}$ condensational growth and evaporation, water vapor equilibrium, particle-particle coagulation and sedimentation removal. These processes are achieved using a non-iterative semi-implicit scheme with an integration time step of $60 \mathrm{sec}-$ onds. The model covers particle sizes from $0.3 \mathrm{~nm}$ to $\sim 1 \mu \mathrm{m}$ diameter, which are geometrically divided into 40 bins.

\section{Results and discussion}

\subsection{Non-NPF events}

There were no typical noontime NPF events during the summer of 2009 in the Michigan forest (Fig. 2a). Out of 5 weeks of continuous measurements, we observed only two abrupt ultrafine particle events (16 July and 2 August) during the early evening time, as opposed to the noontime where wellcharacterized nucleation and persistent growth have been typically observed in locations worldwide (Kulmala et al., 2004). Ultrafine particle events were identified when there was clear evidence of particles ranging in diameter from 3 $10 \mathrm{~nm}\left(N_{3}-10\right)$ and these small particles grew larger for at least three continuous hours. In this section, we examine non-NPF conditions and in the following section, we discuss two early evening ultrafine particle events using trace gas measurements (Fig. 2c) and meteorological parameters (Fig. 2d).

The mean particle concentration in the size range from 3 $10 \mathrm{~nm}$ was $86 \mathrm{~cm}^{-3}$ at noontime. The noontime peak $\mathrm{H}_{2} \mathrm{SO}_{4}$ concentration was $2.6 \times 10^{6} \mathrm{~cm}^{-3}$, and under a very low condensational sink (CS, which is proportional to the measured aerosol surface area density; $1.5 \times 10^{-3} \mathrm{~s}^{-1}$ ) (Fig. 2b), this $\mathrm{H}_{2} \mathrm{SO}_{4}$ concentration should be sufficient to trigger NPF (McMurry et al., 2005), as observed elsewhere in the world, including in Finland boreal forests (Petaja et al., 2009). These results indicate that the relatively clean Michigan forest had favorable conditions during the summer for NPF, 

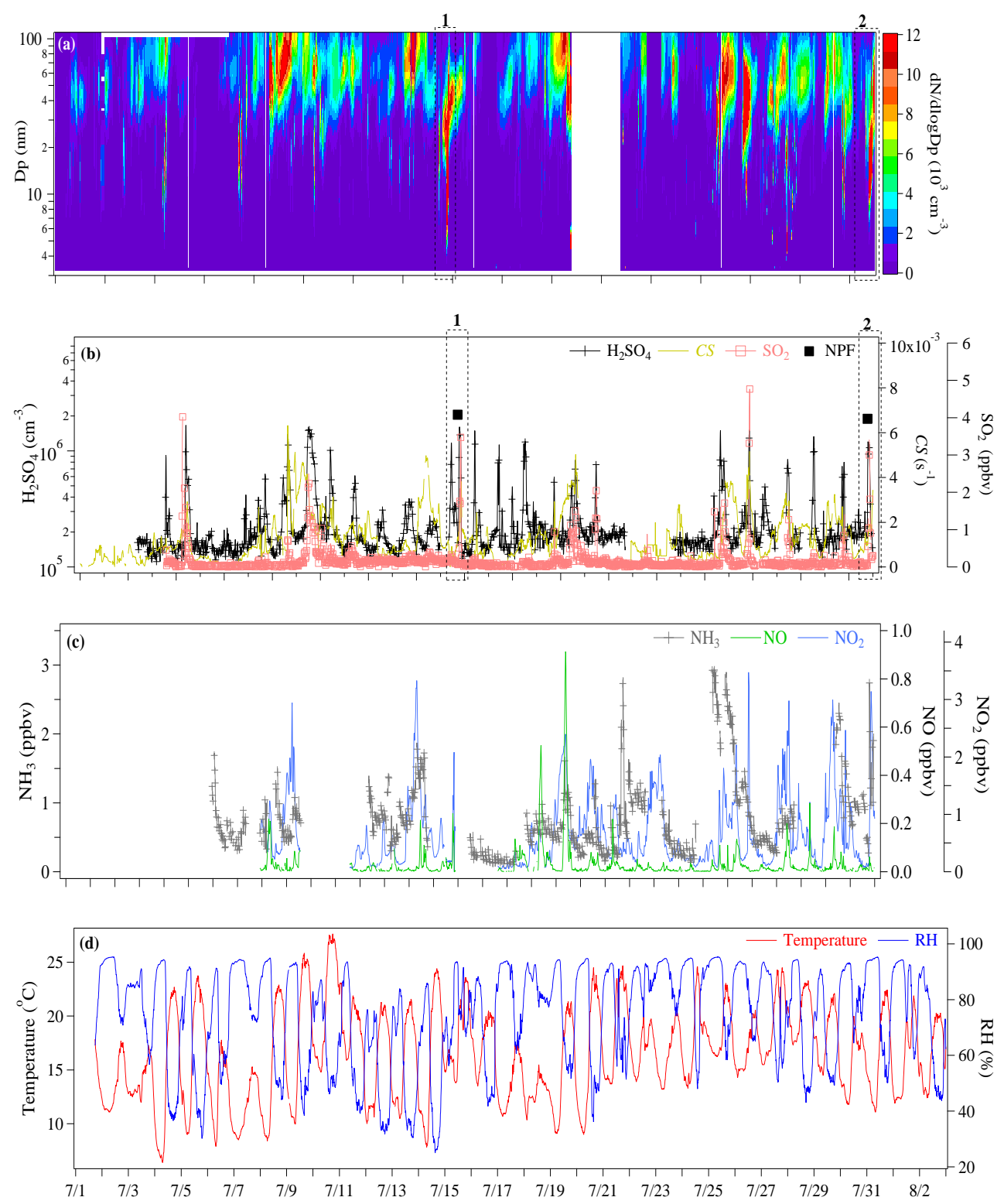

Fig. 2. (a) Particle size distributions in the size range from 3-109 nm measured during 1 July-3 August 2009 in the Michigan forest. There were no NDMA measurements from 22-24 July. (b) The measured $\mathrm{H}_{2} \mathrm{SO}_{4}$ (line with black plus signs), $\mathrm{SO}_{2}$ (light red open squares), and CS (yellow solid line) during 1 July-3 August 2009 at the same site. The two filled black squares show the observed early evening NPF events (Box 1 and 2 for 16 July and 2 August event, respectively). As mentioned in the main text, there were no conventional NPF events at noontime at all during the summer of 2009. Sharp spikes in particle number size distributions were seen at noontime (e.g. 8 July), but these particles did not grow enough to show aerosol size distributions with a typical "banana shape". (c) The measured $\mathrm{NH}_{3}$ (line connected by grey plus signs), $\mathrm{NO}$ (green solid line) and $\mathrm{NO}_{2}$ (light blue solid line), and (d) the measured temperature (red line) and RH (blue line) during 1 July-3 August 2009 at the same site.

given the measured $\mathrm{H}_{2} \mathrm{SO}_{4}$ and CS. Usually the global NPF frequency is lower in the summer $(\sim 10-20 \%)$ and higher in the spring and fall ( $\sim 30-50 \%)$ (Kulmala et al., 2004). Given these observed frequencies, one would expect at least 4-5 days of NPF events during 5 weeks in summer, but the Michigan forest did not show such conventional noontime NPF events at all with the reasonable $\mathrm{H}_{2} \mathrm{SO}_{4}$ and extremely low CS conditions (Fig. 2b). This result suggests that there may be a mechanism in which NPF was "blocked" or "suppressed" in this forested environment.

The Kiendler-Scharr et al. (2009) plant chamber experiments have shown that isoprene suppresses biogenic NPF and such suppression effects were dependent on the ratio $(R)$ of emitted isoprene carbon to MT carbon. They 
Table 1. The ratio of emitted isoprene carbon to $\mathrm{MT}$ carbon, $\mathrm{OH}, \mathrm{H}_{2} \mathrm{SO}_{4}$ and $\mathrm{CS}$ in Michigan, Amazon, and Finland forests. Refer to Table S1 for an overview of emission fluxes and concentrations of isoprene, and MT and corresponding $R$ values.

\begin{tabular}{|c|c|c|c|}
\hline Locations $\quad$ Parameters & Michigan forest ${ }^{\mathrm{a}}$ & Amazon forest ${ }^{b}$ & Finland forest \\
\hline$R$ & $26.4 \pm 4.5$ & 15.2 (Greenberg et al., 2004) & 0.18 (Spirig et al., 2004) \\
\hline $\mathrm{OH}\left(\mathrm{cm}^{-3}\right)^{\mathrm{c}}$ & $1.2-1.5 \times 10^{6}$ & $5.5 \times 10^{6}$ (Martinez et al., 2010) & $7.7 \times 10^{5}$ (Petaja et al., 2009) \\
\hline $\mathrm{H}_{2} \mathrm{SO}_{4}\left(\mathrm{~cm}^{-3}\right)^{\mathrm{c}}$ & $2.6 \times 10^{6}$ & $1-5 \times 10^{5 \mathrm{~d}}$ & $1.4 \times 10^{6}$ (Petaja et al., 2009) \\
\hline $\mathrm{CS}\left(\mathrm{s}^{-1}\right)^{\mathrm{c}}$ & $1.5 \times 10^{-3}$ & $0.9 \pm 0.3(\text { Zhou et al., 2002) })^{\mathrm{e}}$ & $4.2 \times 10^{-3}$ (Kulmala et al., 2001) \\
\hline
\end{tabular}

a this study.

$\mathrm{b}$ data from wet season only.

c noontime peak values.

$\mathrm{d}$ calculated $\mathrm{H}_{2} \mathrm{SO}_{4}$ from the measured $\mathrm{SO}_{2}$ of the order of $0.02-0.03$ ppbv (Andreae and Andreae, 1988) and $\mathrm{OH}$ of $5.5 \times 10^{6} \mathrm{~cm}^{-3}$ (Martinez et al., 2010) over Amazon basin.

e calculated total CS from statistical data (number concentration, geometric mean diameter and geometric standard deviation) for particle size distributions measured during MarchApril 1998 (Zhou et al., 2002).

showed a complete "shutdown" of NPF when $R$ reached $\sim 20$, by increasing isoprene concentrations but keeping other BVOCs constant in their chamber experiment. Our MEGAN model-calculated isoprene and MT emission rates in the Michigan forest were $1.32 \pm 0.7 \mathrm{mgC} \mathrm{m}^{-2} \mathrm{~h}^{-1}$ and $0.05 \pm 0.02 \mathrm{mgC} \mathrm{m}^{-2} \mathrm{~h}^{-1}$, respectively, and thus $R$ was $26.4 \pm 4.5$. We compared the ratio of emitted isoprene carbon to MT carbon at the Michigan site with two other forests with extreme frequencies of NPF events. In Amazon forests where NPF has never been seen (Martin et al., 2010; Zhou et al., 2002), isoprene and MT emission rates ranged between $1.9-8.8 \mathrm{mgC} \mathrm{m}^{-2} \mathrm{~h}^{-1}$ and $0.22-0.76 \mathrm{mgC} \mathrm{m}^{-2} \mathrm{~h}^{-1}$, respectively, and thus $R$ was 15.2 (Greenberg et al., 2004). In contrast, in Finland boreal forests where frequent NPF was observed (Sihto et al., 2006; Makela et al., 1997), isoprene and MT emission rates were $0.03 \mathrm{mgC} \mathrm{m}^{-2} \mathrm{~h}^{-1}$ and $0.16 \mathrm{mgC} \mathrm{m}^{-2} \mathrm{~h}^{-1}$, respectively, and $R$ was 0.18 (Spirig et al., 2004) (Table 1). The $R$ value for this study (26.4) and the higher $R$ value (15.2) from the Amazon forest are consistent with the Kiendler-Scharr et al. (2009) plant chamber study which showed that NPF is inhibited by isoprene at high $R$ values ( $>10$ ). Additionally, the ratio of isoprene to MT concentrations also showed similar $R$ values in these three forests (Table S1).

To directly compare the relative oxidation rates of isoprene and MT by $\mathrm{OH}$ reaction, we also looked at the $\left(k_{\text {isoprene-OH}}[\right.$ isoprene $\left.]\right) /\left(k_{\mathrm{MT}-\mathrm{OH}}[\mathrm{MT}]\right)$ ratio, where $k_{\text {isoprene-OH }}$ and $k_{\mathrm{MT}-\mathrm{OH}}$ are the rate constants for isoprene and MT oxidation with $\mathrm{OH}$, respectively. This ratio is also directly related to $R$. Based on the averaged diurnal variation of isoprene, MT, and $\mathrm{OH}$ concentrations observed in the Michigan forest for 8-16 July 2009 (Fig. 3a), the average noontime peak $\left(k_{\text {isoprene-OH}}[\right.$ isoprene $\left.]\right) /\left(k_{\mathrm{MT}-\mathrm{OH}}[\mathrm{MT}]\right)$ ratio was $\sim 26$ (Fig. 3b). This ratio was also similar to that observed in Amazon forests ( 20) (Kesselmeier et al., 2002). In Finland boreal forests, this ratio was $<1$ (Sellegri et al., 2005) (Fig. 3b). These results further confirm that oxidation of isoprene with $\mathrm{OH}$ dominates over oxidation of MT with
$\mathrm{OH}$ in Michigan and Amazon forests, where NPF was suppressed.

Kiendler-Scharr et al. (2009) also speculated that the isoprene suppression effects on NPF were due to the $\mathrm{OH}$ depletion by isoprene. $\mathrm{OH}$ measurements in the Michigan forest were of the order of $1.2-1.5 \times 10^{6} \mathrm{~cm}^{-3}$ (noontime peak), between those in Amazon forests $\left(5 \times 10^{6} \mathrm{~cm}^{-3}\right)$ (Martinez et al., 2010) and Finland boreal forests $\left(7 \times 10^{5} \mathrm{~cm}^{-3}\right)$ (Petaja et al., 2009). The $\mathrm{OH}$ measurements in 2009 were similar to those measured previously at the same site, which showed that $\mathrm{OH}$ was actually higher than model-predicted (Di Carlo et al., 2004). Di Carlo et al. (2004) also have proposed that that the missing $\mathrm{OH}$ reactivity may be due to some terpenelike temperature dependent unknown BVOC species. And, it is possible that these terpene-like compounds and their oxidation products (such as organic acids and peroxides) could form new particles. Recent observations have also shown possible $\mathrm{OH}$ recycling mechanisms due to isoprene in the presence of low NOx (Lelieveld et al., 2008, Paulot et al., 2009). Hofzumahaus et al. (2009) also suggested two hypothetical $\mathrm{OH}$ recycling reactions involving unknown compound $\mathrm{X}\left(\mathrm{RO}_{2}+\mathrm{X} \rightarrow \mathrm{HO}_{2}\right.$ and $\mathrm{HO}_{2}+\mathrm{X} \rightarrow \mathrm{OH}$, both of the same rate as for the corresponding $\mathrm{NO}$ reactions) for reformation of $\mathrm{OH}$, although the actual chemical identification of $\mathrm{X}$ has not been identified. From these reasons, we believe that isoprene did not suppress $\mathrm{OH}$ concentrations, although the absence of NPF was due to the excessive isoprene concentrations compared to MT.

Recently, Surratt et al. (2010) showed that isoprene-OH oxidation products (e.g., isoprene epoxydiols (IEPOX) at low $\mathrm{NO}_{\mathrm{x}}$ and methacryloylperoxynitrate (MPAN) at high $\mathrm{NO}_{\mathrm{x}}$ conditions) could partition into atmospheric aerosols. Single particle measurements made in the free troposphere far away from the isoprene source regions also identified the presence of organosulfates, indicative of the IEPOX partitioning on acidic sulfate particles, at low $\mathrm{NO}_{\mathrm{x}}$ conditions when total concentrations of MVK and MACR (both primary isoprene oxidation products) exceeded 1.2 ppbv (Froyd et al., 2010). 

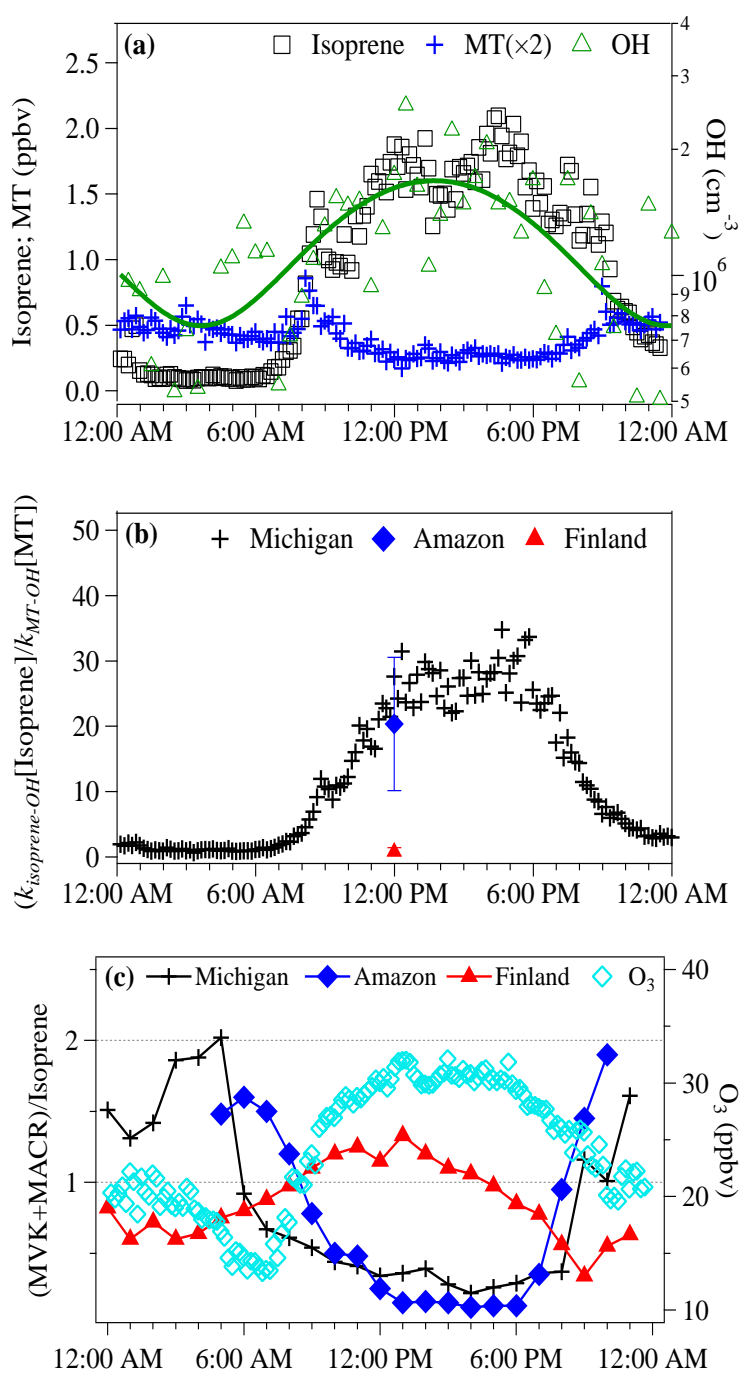

Fig. 3. (a) The average diurnal variation of isoprene (black open squares), MT (blue plus signs) and $\mathrm{OH}$ (open green triangles; green line shows the fitting of $\mathrm{OH}$ data) measured in the Michigan forest. (b) The diurnal variation of $\left(k_{\text {isoprene-OH}}[\right.$ Isoprene] $) /\left(k_{\mathrm{MT}-\mathrm{OH}}[\mathrm{MT}]\right)$ ratio averaged from $8-$ 16 July in the Michigan forest. Gas Chromatography-Mass Spectrometry (GC-MS) measurements for MT speciation show that $\alpha$ pinene was the most abundant MT, comprising $80 \%$ of the total MT mixing ratios. The reaction rate constants used in ratio calculation were $k_{\alpha-\text { pinene-OH}}=53.6 \times 10^{-12} \mathrm{~cm}^{3}$ molecules ${ }^{-1} \mathrm{~s}^{-1}$ and $k_{\text {isoprene- }} \mathrm{OH}=101 \times 10^{-12} \mathrm{~cm}^{3}$ molecules $^{-1} \mathrm{~s}^{-1}$ (FinlaysonPitts and Pitts, 2000; Atkinson et al., 2006). In comparison, ratio values in Amazon (Kesselmeier et al., 2002) (blue diamond) and Finland boreal forests (Sellegri et al., 2005) (red triangle) are also included here; vertical lines indicate one standard deviation in the ratio. (c) The ratios of (MVK+MACR)/isoprene for the Michigan forest (this study) (black line with plus signs), Amazon forests (Kesselmeier et al., 2002) (blue line with filled diamonds) and Finland boreal forests (Rinne et al., 2002) (red line with filled triangles). The measured $\mathrm{O}_{3}$ (cyan open diamonds) in the Michigan forest are also shown.
However, the averaged noontime peak concentration of (MVK+MACR) in the Michigan forest during 8 July-2 August was very low $(\sim 0.25 \mathrm{ppbv})$. The measured $\mathrm{NO}$ and $\mathrm{NO}_{2}$ concentrations at this site were $<0.25 \mathrm{ppbv}$ and $<3.5 \mathrm{ppbv}$, respectively, during the summer 2009 (Fig. 2c). We have calculated the ratio of $\left(k_{1}\left[\mathrm{RO}_{2}\right][\mathrm{NO}]\right) /\left(k_{2}\left[\mathrm{RO}_{2}\right]\left[\mathrm{HO}_{2}\right]\right)$, with the rate constant $k_{1}=7.5-9 \times 10^{-12} \mathrm{~cm}^{3} \mathrm{~s}^{-1}$ (Finlayson-Pitts and Pitts, 2000; Atkinson et al., 2006) relative to $\mathrm{RO}_{2}+\mathrm{NO} \rightarrow$ $\mathrm{RO}+\mathrm{NO}_{2}$ and the rate constant $k_{2}=0.5-1.5 \times 10^{-11} \mathrm{~cm}^{3} \mathrm{~s}^{-1}$ (Finlayson-Pitts and Pitts, 2000; Atkinson et al., 2006) for $\mathrm{RO}_{2}+\mathrm{HO}_{2} \rightarrow \mathrm{ROOH}+\mathrm{O}_{2}$. The calculated daytime ratio was $<0.1$ and suggests that the reaction of organic peroxy radicals with $\mathrm{HO}_{2}$ is predominantly more active than with NO. Thus, the Michigan forest atmosphere during the summer can be considered as a low- $\mathrm{NO}_{\mathrm{x}}$ environment. The (MVK+MACR)/isoprene ratio, which is indicative of the extent of isoprene oxidation, was very low $(\sim 0.2)$, consistent with a previous report at the same site (Apel et al., 2002) (Fig. 3c). These results indicate that the majority of isoprene molecules were not fully oxidized to produce low volatility species such as IEPOX. This trend is also consistent with the Henze and Seinfeld (Henze and Seinfeld, 2006) study showing that isoprene oxidation is often incomplete near the source region due to its high emission rates. The (MVK+MACR)/isoprene ratio measured in the Michigan forest was also surprisingly similar to that in the Amazon forest (Kesselmeier et al., 2002), whereas this ratio was much higher $(>1)$ in the Finland boreal forest (Rinne et al., 2002) (Fig. 3c).

It has been previously postulated that biogenic NPF can be attributed to MT- and SQT-ozone $\left(\mathrm{O}_{3}\right)$ reactions (Bonn and Moortgat, 2003; Hoffmann et al., 1998; O'Dowd et al., 2002; Burkholder et al., 2007). Smog chamber experiments also have shown that $\mathrm{MT}$ reactions with $\mathrm{O}_{3}$ tend to yield more secondary organic aerosols than those with OH radicals (Larsen et al., 2001; Yu et al., 1999). We have calculated the ratio of relative rates of reaction of $\mathrm{MT}$ with $\mathrm{O}_{3}$ and $\mathrm{OH}$ radicals, $\left(k_{M T-O 3}\left[\mathrm{O}_{3}\right] / k_{M T-O H}[\mathrm{OH}]\right)$, where $k_{\mathrm{MT}-\mathrm{O} 3}\left(86.6 \times 10^{-18} \mathrm{~cm}^{3}\right.$ molecule $\left.{ }^{-1} \mathrm{~s}^{-1}\right)$ is the rate constant of MT with $\mathrm{O}_{3}$ (Finlayson-Pitts and Pitts, 2000; Atkinson et al., 2006). The averaged noontime peak $\left(k_{\mathrm{MT}-\mathrm{O} 3}\left[\mathrm{O}_{3}\right] / k_{\mathrm{MT}-\mathrm{OH}}[\mathrm{OH}]\right)$ ratio in the Michigan forest was $0.76 \pm 0.08$, lower by a factor of 2.38 compared to the Finland forest $(1.81 \pm 0.32)$. This ratio was even much lower $(0.14 \pm 0.07)$ in the Amazon forest which is likely due to considerably low $\mathrm{O}_{3}$ concentrations $(<20 \mathrm{ppbv}$, Kesselmeier et al., 2002) during the wet season. These results suggest that the relative rates of reaction of $\mathrm{MT}$ with $\mathrm{O}_{3}$ are dominant in the Finland forest than in the Michigan forest and the Amazon forest.

On the contrary, average MT and SQT concentrations in the Michigan forest were $0.35 \pm 0.24 \mathrm{ppbv}$ (this study) and 0.02 ppbv (Kim et al., 2009), respectively. These values were in fact comparable to those measured in Finland boreal forests (Table $\mathrm{S} 1$ ). The measured $\mathrm{O}_{3}$ concentrations in 
the Michigan forest (e.g., noontime peak $\sim 32 \mathrm{ppbv}$ ) (Fig. 3c) were also comparable to those in the Finland boreal forest (Suni et al., 2003). Despite the similarities in MT, SQT, and $\mathrm{O}_{3}$ concentrations between the Michigan and Finland forests, biogenic NPF did not occur in the Michigan forest and we believe that it has something to do with $R$ rather than the production rate of $\mathrm{MT}-\mathrm{O}_{3}$ reaction products. These results again show that rather than the absolute concentrations of MT or SQT, the $R$ values appear to be more important in regulating biogenic NPF processes. The production of new particles from $\mathrm{O}_{3}$ reactions with MT and SQT (Bonn and Moortgat, 2003; Bonn et al., 2008; Burkholder et al., 2007; Hoffmann et al., 1998; O'Dowd et al., 2002), may be suppressed by isoprene oxidation products such as formaldehyde reacting with stabilized criegee biradicals produced in the ozonolysis reactions, and in turn suppress nucleation.

Another possible explanation for the effects of $R$ on NPF events is that organic acids play an important role in nucleation by clustering with $\mathrm{H}_{2} \mathrm{SO}_{4}$, as was suggested by Zhang et al. (2004, 2009). Bonn et al., (2003) also have shown that large organic acids can be formed from $\alpha$-pinene ozonolysis and it is possible that these large organic acids can participate in biogenic nucleation. However, organic acids formed from isoprene oxidation can be more volatile than those formed from MT, and if they compete with and prevent larger organic acids from clustering with sulfuric acid, NPF could be suppressed.

Comparing Michigan (no NPF), Amazon (no NPF) and Finland boreal forests (frequent NPF), there are two distinctive factors regulating biogenic NPF: $R$ and the ratio of (MVK+MACR)/isoprene. Both Michigan and Amazon forests have much higher concentrations and emission rates of isoprene during the summer than the Finland forest. Given the relatively high concentrations of isoprene, high $R$ values, and the results from the Kiendler-Scharr et al. (2009) plant chamber study, NPF would not occur in Michigan and Amazon forests. In comparison, in Finland forests where the $R$ values and isoprene emissions are substantially lower, NPF took place with a frequency of $\sim 10 \%$ even during the summer (Kulmala et al., 2004). Also, the (MVK+MACR)/isoprene ratio was very low in Michigan and Amazon forests compared to the Finland forest, indicating incomplete oxidation processes for isoprene, due to proximity of the isoprene source relative to the sampling location. Compared to the Michigan forest, additional reasons that Amazon forests did not have NPF events may be very low $\mathrm{H}_{2} \mathrm{SO}_{4}\left(<5 \times 10^{5} \mathrm{~cm}^{-3}\right)$ due to low $\mathrm{SO}_{2}[0.02-0.03 \mathrm{ppbv}$, Andreae and Andreae, 1988), found in pristine conditions and the extraordinarily high aerosol surface area (Table 1) due to high concentrations of primary biogenic aerosols.

Suni et al. (2008) have shown frequent nighttime events of charged ion cluster growth measured by an air ion spectrometer (AIS) in southern Australia under high isoprene emission conditions, and these results may appear to be inconsistent with isoprene suppression of NPF. But another study (Suni et al., 2009) also showed that this forest site was strongly influenced by the marine air masses, so this may not be a pure biogenic environment. This site is also unique in terms of showing very frequent ion cluster growth events even in the winter, so it was possible that the IIN process was important in this forest. As AIS only measures charged clusters, it is difficult to directly compare ion cluster growth events determined by AIS with NPF events reported by a regular differential mobility analyzer (DMA, TSI 3085). For example in Finland boreal forests, when AIS showed nighttime ion cluster growth events, DMA-measured size distributions did not show NPF (Kulmala et al., 2004), because small clusters identified by AIS (2-4 nm) did not grow further to be measured by DMA (Junninen et al., 2008).

\subsection{Two early evening ultrafine particle events}

While there were no conventional noontime NPF events from the Michigan forest, there were two early evening ultrafine particle events (16 July and 2 August) both between 18:3021:30 local time. These two evening events had strikingly similar features in trace gases and particle number concentrations, and they both were associated with high $\mathrm{SO}_{2}$. For example, during the 16 July event, $N_{3-10}\left(\sim 100-7000 \mathrm{~cm}^{-3}\right)$ were closely correlated with the simultaneous rise of $\mathrm{SO}_{2}$ (maximum $>3 \mathrm{ppbv}$, one order of magnitude higher than the background $\mathrm{SO}_{2}, \sim 0.2$ ppbv) and $\mathrm{H}_{2} \mathrm{SO}_{4}$ (in the range of 1$2 \times 10^{6} \mathrm{~cm}^{-3}$ ) (Fig. 4a). The in-situ measured $\mathrm{NO}$ and $\mathrm{NO}_{2}$ were also well-correlated with the abrupt rise of $\mathrm{SO}_{2}$ (correlation coefficient of 0.89), suggesting an anthropogenic origin of the plume. These results thus strongly suggest that the observed ultrafine particles were not produced locally, rather transported along with anthropogenic sulfur plumes. Around noontime, there was a very small increase in $N_{3-10}$ from $\sim 100-1000 \mathrm{~cm}^{-3}$ (e.g., 16 July, Fig. 4a). However, these particles did not grow enough to show aerosol size distributions with a typical "banana shape" (found in conventional NPF events, for example, (Kulmala et al., 2004)). During the 2 August event, $\mathrm{NH}_{3}$ was also fairly correlated with $\mathrm{N}_{3-10}$, with the highest mixing ratio of $2.7 \mathrm{ppbv}$; there were no $\mathrm{NH}_{3}$ measurements on 16 July (Fig. 2c).

In order to localize the anthropogenic plume source, we have used a combination of satellite-based observation of the tropospheric $\mathrm{NO}_{2}$ column and back trajectory information (Fig. 5). Air masses over the Michigan forest site oscillated between those originating from relatively clean regions in the north $\left(\mathrm{NO}_{2}<1 \times 10^{15}\right.$ molecules $\left.\mathrm{cm}^{-2}\right)$ and those originating from polluted regions to the southwest or south $\left(\mathrm{NO}_{2}>5 \times 10^{15}\right.$ molecules $\left.\mathrm{cm}^{-2}\right)$. Remarkably, on the two ultrafine particle event days, air parcel back trajectories passed near Minneapolis, Minnesota, where a large coal-fired power plant (Sherburne Power Plant, SPP) is located, about $35 \mathrm{~h}$ (16 July) and $30 \mathrm{~h}$ (2 August) prior to arriving at the measurement site. On 31 July, the air parcel back trajectories pass close to Minneapolis but we did not observe ultrafine 

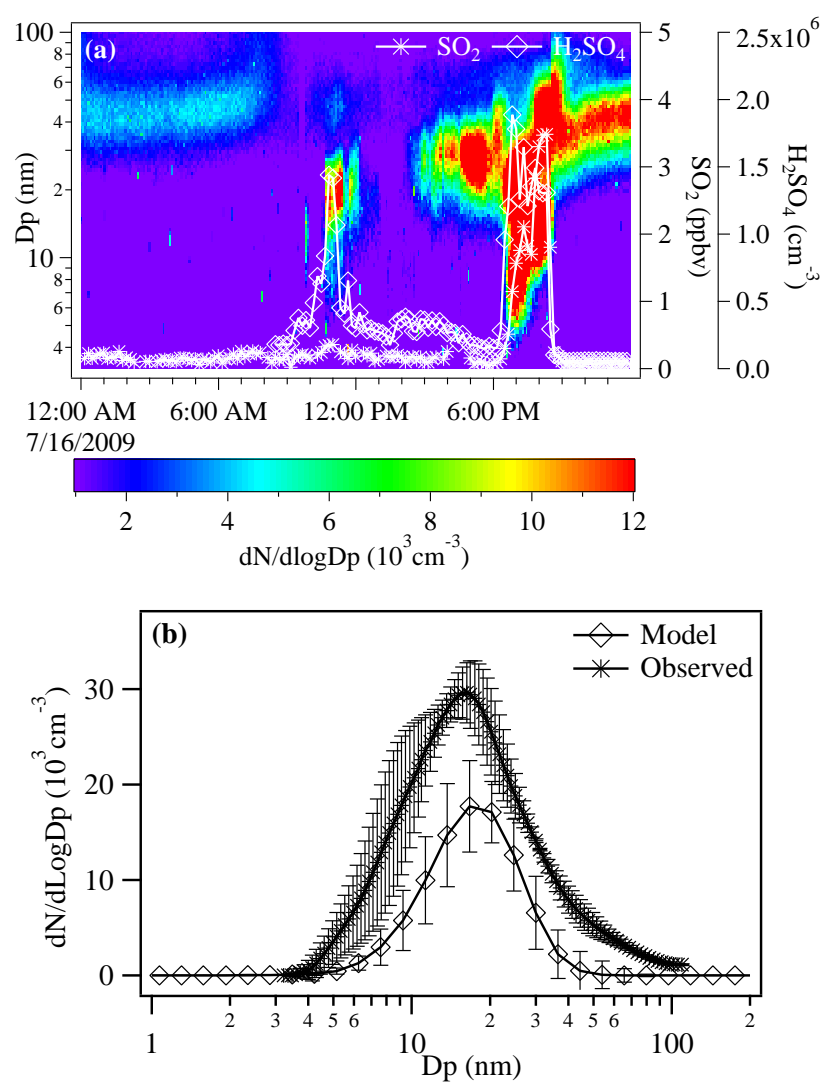

Fig. 4. (a) Particle number size distributions, $\mathrm{SO}_{2}$ (white asterisks) and $\mathrm{H}_{2} \mathrm{SO}_{4}$ (white open diamonds) measured on 16 July 2009. The 2 August evening event also showed a strikingly similar feature as here. (b) The size distributions predicted from the model at the end of $35 \mathrm{~h}$ simulation (line with open diamonds) and that measured at the forest site at 19:00 LT (line with asterisks). The vertical bars indicate one standard deviation values. Considering uncertainties in measurements and modeling simulations, this is a very good agreement. IIN simulations for the 2 August event also showed very similar results.

particles due to persistent rain that scavenged ultrafine particles.

To investigate the nucleation mechanism that might be responsible for the observed ultrafine particles on these two events, we performed aerosol microphysical box model simulations, incorporated with an IIN parameterization (Lovejoy et al., 2004), using the measured key aerosol precursor concentrations such as $\mathrm{SO}_{2}, \mathrm{OH}$, and $\mathrm{H}_{2} \mathrm{SO}_{4}$. These two events had very similar features in the air mass history (Fig. 5), temperature, relative humidity $(\mathrm{RH})$, wind direction and wind speed (Fig. S1). The initial conditions for the box model simulations for two ultrafine particle events (16 July and 2 August) were chosen in the following manner: (i) temperature and RH were taken from the back trajectory calculations at each hour; (ii) the initial particle surface area density (SA) $\left(2.25 \mu \mathrm{m}^{2} \mathrm{~cm}^{-3}\right)$ was taken from the average value of the measured particle size distributions on a clean day to rep-

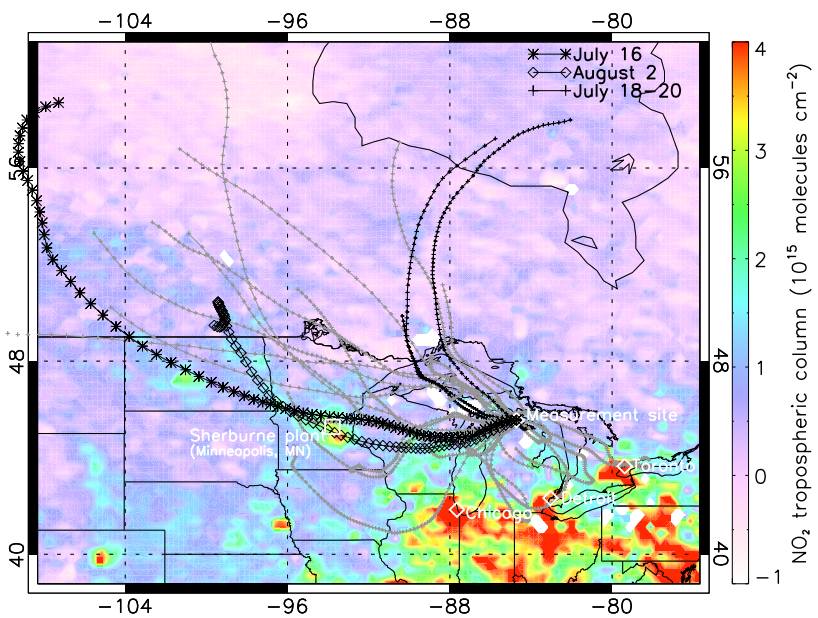

Fig. 5. The SCIAMACHY-retrieved 0.25 degree gridded tropospheric $\mathrm{NO}_{2}$ column data from June-August 2009. The locations of the UMBS site and the nearby large urban centers are shown by white open diamonds. The white open square shows the location of the SPP, which was ranked 29th in US Environmental Protection Agency (EPA) region 5 (IL, IN, MI, MN, OH and WI) in 2009 for $\mathrm{SO}_{2}$ emissions (24015.8 tons) and 6th by $\mathrm{NO}_{\mathrm{X}}$ (13873.7 tons) under Acid Rain Program (ARP) sources (http://camddataandmaps.epa. gov/gdm/). The HYSPLIT-calculated 3-day backward trajectories starting at $10 \mathrm{~m}$ at 19:00 LT from 8 July-2 August are also shown, highlighting the two early evening NPF events on 16 July (black line with stars) and 2 August (black line with open diamonds) and very clean non-event days (18-20 July) (black line with plus sign).

resent the low SA, as both trajectories experienced rain before passing the SPP in Minnesota, MN (where model simulations started; that is, the model running time $t=0$ ). As the model simulations proceeded, the total SA at each time step was continuously updated based on the evolved aerosol size distributions;

$\mathrm{SA}_{i, t}=\sum_{i=1}^{i=n} \pi d_{i}^{2} N_{i, t}$

where $n$ is the number of size bins $(i=1,2,3,,, 40), d_{i}$ the particle diameter in the $i$ th size bin, and $N_{i, t}$, and $\mathrm{SA}_{i, t}$ the particle number concentration and surface area density in the $i$ th size bin at time $t$, respectively. The semi-sinusoidal shaped, diurnal variation of $\mathrm{OH}$ along the trajectories was taken from the average $\mathrm{OH}$ diurnal variation measured at the forest site during 8-16 July 2009. A sensitivity test for the prescribed $\mathrm{OH}$ diurnal cycle was also performed by decreasing and increasing averaged $\mathrm{OH}$ diurnal cycle by a factor of two, to account for possible $\mathrm{OH}$ variations due to $\mathrm{NO}_{\mathrm{x}}$ conditions in plumes. The sensitivity analysis showed that the mode diameter shifts to higher particle diameter (within the $1 \sigma$ variation) with increasing $\mathrm{OH}$ and the number concentrations do not change significantly. The contribution of the transported anthropogenic $\mathrm{SO}_{2}$ downwind of the emission region was very simply estimated by taking into account its 
atmospheric lifetime (Kunhikrishnan et al., 2004) using the following equation;

$C=C_{0} \times e^{\left(-\frac{t_{\text {trans }}}{\tau}\right)}$

where $C_{0}$ is the initial $\mathrm{SO}_{2}$ at the source region (which is the unknown value); $C$ is the concentration after the time $t_{\text {trans }}$ (3.5 ppbv measured at the forest site on the both the event days); $\tau$ is the atmospheric lifetime of $\mathrm{SO}_{2}$ due to its chemical (via reaction with $\mathrm{OH}$ ) and depositional losses $[\tau \approx 20 \mathrm{~h}$ in summer, Pham et al., 1995]; and $t_{\text {trans }}$ is the transport time between SPP and the forest measurement site (35 h taken from trajectory calculations). Based on this method, we have set the initial $\mathrm{SO}_{2}$ of $15 \mathrm{ppbv}$ at $\mathrm{SPP}$, which is somewhat less than, but still within the order of, the $\mathrm{SO}_{2}$ measured in power plant plumes (maximum $\sim 70 \mathrm{ppbv}$ ) (Sorooshian et al., 2006). $\mathrm{SO}_{2}$ at each subsequent time step was further calculated from Eq. (2). The initial $\mathrm{H}_{2} \mathrm{SO}_{4}$ was set as $5 \times 10^{7} \mathrm{~cm}^{-3}$ near SPP, consistent with a measurement made in power plant plumes (McMurry et al., 2005). $\mathrm{H}_{2} \mathrm{SO}_{4}$ in the air parcel during transport was updated by taking into account the loss of $\mathrm{H}_{2} \mathrm{SO}_{4}$ by particle nucleation and growth and production from the reaction $\mathrm{OH}+\mathrm{SO}_{2} \rightarrow \mathrm{HSO}_{3}\left(k_{3}=9.4 \times 10^{-13}\right.$ $\mathrm{cm}^{3} \mathrm{~s}^{-1}$ at $298 \mathrm{~K}$, Finlayson-Pitts and Pitts, 2000) and the prescribed $\mathrm{SO}_{2}$ and $\mathrm{OH}$ at each time step described above. Ion production rate $(Q)$ of 2 ion pairs $\mathrm{cm}^{-3} \mathrm{~s}^{-1}$ was used to represent the typical lower troposphere conditions (Rosen et al., 1985). Figure $\mathrm{S} 2$ shows these prescribed parameters in detail for the 16 July event; the prescribed parameters for the 2 August event were very similar.

With these prescribed and measured key atmospheric parameters (Fig. S2), IIN model simulations showed very similar features for both the ultrafine particle events. The IIN results showed that the nucleation burst occurred at the very first time step (time, $t=1 \mathrm{~h}$ ) due to high $\mathrm{H}_{2} \mathrm{SO}_{4}$ in the plume (Fig. S2). These freshly nucleated particles grew slowly over a day during the transport and reached sizes $>4 \mathrm{~nm}$ at $t=35 \mathrm{~h}$. The model predicted $N_{3-10}$ and particle size distribution at the end of the model run (at the time when air masses arrived at the forest site) are in good agreement with the observed $N_{3-10}$ and particle size distribution on both event days (Fig. $4 \mathrm{~b}$ for 16 July event). These results imply that IIN involving high concentrations of $\mathrm{SO}_{2}$ and $\mathrm{H}_{2} \mathrm{SO}_{4}$ can explain the observed ultrafine particles in the Michigan forest under the influence of an intense sulfur plume. In comparison, IIN simulations for non-event days (e.g., 20 July), where air masses originated from clean regions to the north of the forest site, showed no nucleation due to low $\mathrm{H}_{2} \mathrm{SO}_{4}$, even with the sufficiently low CS.

Our IIN simulation results are different from Boy et al. (2008), which showed that IIN fails to reproduce the measured ultrafine particle concentrations in Finland boreal forests. Compared to Boy et al. (2008), our simulations indicate that nucleation occurred rapidly in the sulfur plumes, because the conditions were more favorable for nucleation due to the higher $\mathrm{SO}_{2}$ and $\mathrm{H}_{2} \mathrm{SO}_{4}$. The air masses also experienced rain events before arriving at SPP (as seen from backward trajectory calculations) to allow very low surface areas. The high $\mathrm{H}_{2} \mathrm{SO}_{4}$ and low surface area thus provided an ideal condition for nucleation. Our results are, on the other hand, consistent with Brock et al. (2004), showing that the high $\mathrm{SO}_{2}$ in power plant plumes can trigger IIN and these freshly nucleated particles can be transported over long distances to less polluted regions. At present, we cannot address if other classical homogeneous nucleation processes such as binary or ternary homogeneous nucleation (BHN or TNH) besides IIN also played a role in these sulfur plumes, since the current BHN (Vehkamäki et al., 2002) and THN (Merikanto et al., 2007) theories are highly uncertain to make high fidelity simulations.

We have further calculated particle growth rates (GR) from the measured particle size distribution data. GR derived from the measured aerosol size distributions were $5.5 \pm 1.9 \mathrm{~nm} \mathrm{~h}^{-1}$ and $6.6 \pm 0.7 \mathrm{~nm} \mathrm{~h}^{-1}$ on 16 July (Fig. 3a) and 2 August, respectively. These growth rates are also within the same order as those measured in Finland boreal forests (Sihto et al., 2006; Makela et al., 1997), European coniferous forests (Held et al., 2004) and African savanna forests (Laakso et al., 2008) $\left(2-10 \mathrm{~nm} \mathrm{~h}^{-1}\right)$. However, the calculated GR from condensation of $\mathrm{H}_{2} \mathrm{SO}_{4}$ alone were 0.14 and $0.11 \mathrm{~nm} \mathrm{~h}^{-1}$ on 16 July and 2 August, respectively, accounting for only 2$3 \%$ of the measured GR. These results suggest that species other than $\mathrm{H}_{2} \mathrm{SO}_{4}$, such as BVOC oxidation products, may play a major role in the growth of nucleation-mode particles over the forest, consistent with field observations (Sellegri et al., 2005) and laboratory experiments (Zhang et al., 2009) showing that oxidation products of BVOCs can contribute to growth of newly formed nano-particles in the biogenic environment.

\section{Conclusions and atmospheric implications}

While many studies have been devoted to understanding how new particles form in the boundary layer, the conditions necessary for NPF event are not well understood despite the ubiquity and the global occurrence of NPF (Kulmala et al., 2004). We present a comprehensive observation of ultrafine particles in the Michigan forest, which showed that conventional NPF did not occur in a mixed deciduous forest, where biogenically emitted isoprene was abundant. These findings are in line with a Kiendler-Scharr et al. (2009) plant chamber study showing that isoprene suppresses NPF. These results thus provide the first atmospheric evidence that the specific pattern of the emitted BVOCs can affect secondary aerosol formation in biogenic environments. While our atmospheric observations show that isoprene indeed suppresses NPF, our measurements also show that $\mathrm{OH}$ was not depleted in the Michigan forest, although such $\mathrm{OH}$ depletion may occur in well-controlled chamber experiments (Kiendler-Scharr et al., 
2009). At present, the underlying mechanism of how biogenic NPF is inhibited by isoprene is not clear and future studies are required to answer this important atmospheric science question. While there was a lack of NPF in this mixed forest, we also showed that ultrafine particles can be formed via IIN in a sulfur-rich plume. Once they were transported to the forest, these ultrafine particles grew rapidly by species other than $\mathrm{H}_{2} \mathrm{SO}_{4}$, including oxidation products of BVOCs. These results are consistent with the recent study which showed that biogenic secondary aerosol formation can be promoted by anthropogenic influences (Froyd et al., 2010; Zhang et al., 2009).

The present-day forests in Northern Michigan are largely composed of tree species such as bigtooth aspen with fewer numbers of white pine, red maple, red oak and paper birch (Ortega et al., 2007). However, about $70 \%$ of aspen trees in the northern Michigan forest are $\sim 50$ years old and the forest average age is greater than other mixed deciduous forests in the Great Lake region, thus beyond peak biomass production (Gough et al., 2007). This suggests a widespread change in the forest structure and composition, for example, shifting from aspen trees (isoprene emitter) to pine trees (MT and SQT emitter), and the subsequent changes in carbon cycling dynamics (Bergen and Dronova, 2007). Indeed, an observation study (Mielke et al., 2010) showed that the MT concentrations have been increasing at this site over the past decade. When switching from bigtooth aspen to white pine tree species, $R$ can be reduced to less than 1 (Ortega et al., 2007). As a result, one should expect a substantial increase in NPF events in the coming decade, thus increasing the aerosol cooling effect over Michigan forests. A recent study using a coupled global atmosphere-land model suggested an increase in isoprene $(22 \%)$ and MT $(18 \%)$ by 2100 , as a result of the increased temperature $\left(1.8^{\circ} \mathrm{C}\right)$ (Heald et al., 2008), but this temperature increase alone may not affect the $R$ values on a global scale. However, little is known about the adaptation of isoprene and MT emitters to longterm changes in temperature. Isoprene and MT emissions may react very differently to other factors, such as increasing $\mathrm{CO}_{2}$ concentrations, which could lead to a much lower $R$ value in many regions (Heald et al., 2009). Many forests, including some in Michigan (Bergen and Dronova, 2007), are experiencing rapid changes in environmental conditions as a result of forest succession, land-use change, human activities, and climate change and their radiative effects need to be incorporated into global aerosol models.

Acknowledgements. The PROPHET 2009 CABINEX campaign was supported by NSF (ATM-0904144). SHL gratefully acknowledges funding support from NSF (CAREER ATM-0645567) NOAA (NA08OAR4310537), and Ohio Board Regents. SNT was supported through DST ICRP and ISRO GBP. We also thank the CABINEX organizers and science team members, especially Steven Bertman, Mary Ann Carroll, Paul Shepson, Kimberly Edwards, and Alex Bryan; Li-Hao Young and Dave Benson for experimental assistances; Greg Huey and Dave Tanner for technical support on CIMS; Phil Stevens and Sebastien Dusanter for providing $\mathrm{OH}$ measurements; Barry Lefer for providing $\mathrm{SO}_{2}$ data; Farahnaz Khosrawi for performing $\mathrm{BHN}$ simulations. We also acknowledge the free use of SCIAMACHY, onboard European ENVISAT spacecraft, tropospheric $\mathrm{NO}_{2}$ data (http://www.temis.nl), NOAA ARL HYSPLIT transport model data (http://ready.arl.noaa.gov), and Environmental Protection Agency (EPA) $\mathrm{SO}_{2}$ and $\mathrm{NO}_{\mathrm{x}}$ data under the Acid Rain Program (http://camddataandmaps.epa.gov/gdm/). We also thank reviewers for useful comments and suggestions.

Edited by: A. Hofzumahaus

\section{References}

Andreae, M. O. and Andreae, T. W.: The cycle of biogenic sulfurcompounds over the Amazon basin: 1. Dry season, J. Geohpys. Res., 93(D2), 1487-1497, 1988.

Apel, E. C., Riemer, D. D., Hills, A., Baugh, W., Orlando, J., Faloona, I., Tan, D., Brune, W., Lamb, B., Westberg, H., Carroll, M. A., Thornberry, T., and Geron, C. D.: Measurement and interpretation of isoprene fluxes and isoprene, methacrolein, and methyl vinyl ketone mixing ratios at the prophet site during the 1998 intensive, J. Geohpys. Res., 107(D3), doi:10.1029/2000JD000225, 2002.

Atkinson, R., Baulch, D. L., Cox, R. A., Crowley, J. N., Hampson, R. F., Hynes, R. G., Jenkin, M. E., Rossi, M. J., and Troe, J.: Evaluated kinetic and photochemical data for atmospheric chemistry: Volume II - gas phase reactions of organic species, Atmos. Chem. Phys., 6, 3625-4055, doi:10.5194/acp-6-3625-2006, 2006.

Ball, S. M., Hanson, D. R., Eisele, F. L., and McMurry, P. H.: Laboratory studies of particle nucleation: Initial results for $\mathrm{H}_{2} \mathrm{SO}_{4}$, $\mathrm{H}_{2} \mathrm{O}$, and $\mathrm{NH}_{3}$ vapors, J. Geophys. Res., 104(D19), 23709237180, doi:10.1029/1999JD900411, 1999.

Barket Jr., D., Hurst, J., Couch, T., Colorado, A., Shepson, P., Riemer, D., Hills, A., Apel, E., Hafer, R., Lamb, B., Westbersg, H., Farmer, C., Stabenau, E., and Zika, R.: Intercomparison of automated methodologies for determination of ambient isoprene during the prophet 1998 summer campaign, J. Geohpys. Res., 106(D20), 24301-24313, doi:10.1029/2000JD900562, 2001.

Benson, D. R., Young, L. H., Kameel, R., and Lee, S.-H.: Laboratory-measured sulfuric acid and water homogeneous nucleation rates from the $\mathrm{SO}_{2}+\mathrm{OH}$ reaction, Geophys. Res. Lett., 35, L11801, doi:11810.11029/12008GL033387, 2008.

Benson, D. R., Erupe, M. E., and Lee, S.-H.: Laboratorymeasured $\mathrm{H}_{2} \mathrm{SO}_{4}-\mathrm{H}_{2} \mathrm{O}-\mathrm{NH}_{3}$ ternary homogeneous nucleation rates: Initial observations, Geophys. Res. Lett., 36, L15818, doi:10.1029/2009GL038728, 2009

Benson, D. R., Al-Refai, M., and Lee, S.-H.: Chemical ionization mass spectrometer (CIMS) for ambient measurements of ammonia, Atmos. Meas. Techn., 3, 1075-1087, doi:10.5194/amt-1010775-2010, 2010.

Benson, D. R., Yu, J. H., Markovich, A., and Lee, S.-H.: Ternary homogeneous nucleation of $\mathrm{H}_{2} \mathrm{SO}_{4}, \mathrm{NH}_{3}$, and $\mathrm{H}_{2} \mathrm{O}$ under conditions relevant to the lower troposphere, Atmos. Chem. Phys., 11, 4755-4766, doi:10.5194/acp-11-4755-2011, 2011.

Bergen, K. M. and Dronova, I.: A remote sensing-ecosystem approach to observing succession on aspen-dominated landscapes, 
Landsc. Ecol., 22, 1395-1410, 2007.

Bonn, B., and Moortgat, G. K.: Sesquiterpene ozonolysis: Origin of atmospheric new particle formation from biogenic hydrocarbons, Geophys. Res. Lett., 30, 1585, doi:1510.1029/2003GL017000, 2003.

Bonn, B., Kulmala, M., Riipinen, I., Sihto, S.-L., and Ruuskanen, T. M.: How biogenic terpenes govern the correlation between sulfuric acid concentrations and new particle formation, J. Geophys. Res., 113, D12209, doi:10.1029/2007JD009327, 2008.

Bovensmann, H., Burrows, J. P., Buchwitz, M., Frerick, J., Noël, S., Rozanov, V. V., Chance, K. V., and Goede, A. P. H.: SCIAMACHY- mission objectives and measurement modes, J. Atmos. Sci., 56, 121-150, 1999.

Boy, M., Kazil, J., Lovejoy, E. R., Guenther, A., and Kulmala, M.: Relevance of ion-induced nucleation of sulfuric acid and water in the lower troposphere over the boreal forest at northern latitudes, Atmos. Res., 90, 151-158, 2008.

Brock, C. A., Hudson, P. K., Lovejoy, E. R., Sullivan, A., Nowak, J. B., Huey, L. G., Cooper, O. R., Cziczo, D. J., Gouw, J., Fehsenfeld, F. C., Holloway, J. S., Hübler, G., Lafleur, B. G., Murphy, D. M., Neuman, J. A., Nicks Jr., D. K., Orsini, D. A., Parrish, D. D., Ryerson, T. B., Tanner, D. J., Warneke, C., Weber, R. J., and Wilson, J. C.: Particle characteristics following cloud-modified transport from Asia to north America, J. Geophys. Res., 109, D23S26, doi:10.1029/2003JD004198, 2004.

Burkholder, J. B., Baynard, T., Ravishankara, A. R., and Lovejoy, E. R.: Particle nucleation following the $\mathrm{O}_{3}$ and $\mathrm{OH}$ initiated oxidation of $\alpha$-pinene and b-pinene between 278 and $320 \mathrm{k}$, J. Geophys. Res., 112, D10216, doi:10.1029/2006JD007783, 2007.

Carroll, M. A., Bertman, S. B., and Shepson, P. B.: Overview of the Program for Research on Oxidants: PHotochemistry, Emissions, and Transport (PROPHET) summer 1998 measurements intensive, J. Geophys. Res., 106(D20), doi:10.1029/2001JD900189, 2001.

Claeys, M., Graham, B., Vas, G., Wang, W., Vermeylen, R., Pashynska, V., Cafmeyer, J., Guyon, P., Andreae, M. O., Artaxo, P., and Maenhaut, W.: Formation of secondary organic aerosols through photooxidation of isoprene, Science, 303, 1173-1176, 2004.

Cooper, O. R., Moody, J. L., Thornberry, T. D., Town, M. S., and Carroll, M. A.: PROPHET 1998 meteorological overview and air-mass classification, J. Geophys. Res., 106(D20), 2428924299, doi:10.1029/2000JD900409, 2001.

de Gouw, J. and Warneke, C.: Measurements of volatile organic compounds in the earth's atmosphere using proton-transferreaction mass spectrometry, Mass Spectrom. Rev., 26, 223-257, 2007.

Delia, A. E.: Real-time measurements of non-refractory particle composition and interactions at forested sites, $\mathrm{PhD}$ Thesis, Department of Astrophysical, Planetary and Atmospheric Sciences, University of Colorado, USA, 2004.

Di Carlo, P., Brune, W. H., Martinez, M., Harder, H., Lesher, R., Ren, X., Trobberry, T., Carroll, M. A., Young, V., Shepson, P. B., Riemer, D., Apel, E., and Cambell, C.: Missing OH reactivity in a forest: Evidence for unknown reactive biogenic VOCs, Science, 304, 722-725, 2004.

Draxler, R. R., and Rolph, G. D.: HYSPLIT (HYbrid SingleParticle Lagrangian Integrated Trajectory) model access via NOAA ARL ready website (http://ready.Arl.Noaa.Gov/hysplit. Php), NOAA Air Resources Laboratory, Silver Spring, MD,
USA, 2010.

Dusanter, S., Vimal, D., Stevens, P. S., Volkamer, R., and Molina, L.: Measurements of $\mathrm{OH}$ and $\mathrm{HO}_{2}$ concentrations during the MCMA-2006 field campaign: Part 1 - deployment of the indiana university laser-induced fluorescence instrument, Atmos. Chem. Phys., 9, 1665-1685, doi:10.5194/acp-9-1665-2009, 2009.

Erupe, M. E., Benson, D. R., Li, J., Young, L.-H., Verheggen, B., Al-Refai, M., Tahboub, O., Cunningham, V., Frimpong, F., Viggiano, A. A., and Lee, S.-H.: Correlation of aerosol nucleation rate with sulfuric acid and ammonia in kent ohio: An atmospheric observation, 2010, 115, D23216, doi:10.1029/2010JD013942, 2010.

Finlayson-Pitts, B. J. and Pitts, J. N.: Chemistry of the upper and lower atmosphere: Theory, experiments, and applications, Academic Press, San Diego, CA, 2000.

Froyd, K. D. and Lovejoy, E. R.: Experimental thermodynamics of cluster ions composed of h2so4 and h2o: 1. Positive ions, J. Phys. Chem. A, 107, 9800-9811, 2003.

Froyd, K. D., Murphy, S. M., Murphy, D. M., de Gouw, J. A., Eddingsaas, N. C., and Wennberg, P. O.: Contribution of isoprenederived organosulfates to free tropospheric aerosol mass, Proc. Natl. Acad. Sci., USA, 107, 21360-21365, 2010.

Goldstein, A. H. and Galbally, I. E.: Known and unexplored organic constituents in the earth's atmosphere, Environ. Sci. Technol., 41, 1514-1521, 2007.

Gough, C. M., Vogel, C. S., Harrold, K. H., George, K., and Curtis, P. S.: The legacy of harvest and fire on ecosystem carbon storage in a north temperate forest, Global Change Biol., 13, 1935-1949, 2007.

Greenberg, J., Guenther, A., Petron, G., Wiedinmyer, C., Vega, O., Gatti, L. V., Tota, J., and Fisch, G.: Biogenic voc emissions from forested Amazonian landscapes, Global Biogeochem. Cy., 10, 651-662, 2004.

Guenther, A., Karl, T., Harley, P., Wiedinmyer, C., Palmer, P. I., and Geron, C.: Estimates of global terrestrial isoprene emissions using MEGAN (Model of Emissions of Gases and Aerosols from Nature), Atmos. Chem. Phys., 6, 3181-3210, doi:10.5194/acp-63181-2006, 2006.

Guenther, A. B., Hewitt, C. N., Erickson, D., Fall, R., Geron, C., Graedel, T., Harley, P., Klinger, L., Lerdau, M., McKay, W. A., Pierce, T., Scholes, B., Steinbrecher, R., Tallamraju, R., and Zimmerman, P.: A global model of natural volatile organic compound emissions, J. Geophys. Res., 100(D5), 8873-8892, doi:10.1029/94JD02950, 1995.

Hallquist, M., Wenger, J. C., Baltensperger, U., Rudich, Y., Simpson, D., Claeys, M., Dommen, J., Donahue, N. M., George, C., Goldstein, A. H., Hamilton, J. F., Herrmann, H., Hoffmann, T., Iinuma, Y., Jang, M., Jenkin, M. E., Jimenez, J. L., KiendlerScharr, A., Maenhaut, W., McFiggans, G., Mentel, T. F., Monod, A., Prevot, A. S. H., Seinfeld, J. H., Surratt, J. D., Szmigielski, R., and Wildt, J.: The formation, properties and impact of secondary organic aerosol: Current and emerging issues, Atmos. Chem. Phys., 9, 5155-5236, doi:10.5194/acp-9-5155-2009, 2009.

Heald, C. L., Henze, D. K., Horowitz, L. W., Feddema, J., Lamarque, J.-F., Guenther, A., Hess, P. G., Vitt, F., Seinfeld, J. H., Goldstein, A. H., and Fung, I.: Predicted change in global secondary organic aerosol concentrations in response to future climate, emissions, and land use change, J. Geohpys. Res., 113, 
D05211, doi:10.1029/2007JD009092, 2008.

Heald, C. L., Wilkinson, M. J., Monson, R. K., Alo, C. A., Wang, G., and Guenther, A.: Response of isoprene emission to ambient $\mathrm{CO}_{2}$ changes and implications for global budgets, Global Change Biol., 15, 1127-1140, 2009.

Held, A., Nowak, A., Birmili, W., Wiedensohler, A., Forkel, R., and Klemm, O.: Observations of particle formation and growth in a mountainous forest region in central europe, J. Geophys. Res., 109, D23204, doi:10.1029/2004JD005346, 2004.

Henze, D. K. and Seinfeld, J. H.: Global secondary organic aerosol from isoprene oxidation, Geophys. Res. Lett, 33, L09812, doi:10.1029/2006GL025976, 2006.

Hoffmann, T., Bandur, R., Marggraf, U., and Linscheid, M.: Molecular composition of organic aerosols formed in the $\alpha$-pinene $/ \mathrm{O}_{3}$ reaction: Implications for new particle formation processes, J. Geophys. Res., 103(D19), doi:10.1029/98JD01816, 1998.

Hofzumahaus, A., Rohrer, F., Lu, K. D., Bohn, B., Brauers, T., Chang, C. C., Fuchs, H., Holland, F., Kita, K., Kondo, Y., Li, X., Lou, S. R., Shao, M., Zeng, L. M., Wahner, A., and Zhang, Y. H.: Amplified Trace Gas Removal in the Troposphere, Science 324, 1702-1704, 2009.

Junninen, H., Hulkkonen, M., Riipinen, I., Nieminen, T., Hirsikko, A., Suni, T., Boy, M., Lee, S.-H., Vana, M., Tammet, H., and Kulmala, M.: Observations on night time growth of atmospheric clusters, Tellus B, 60B, 365-371, 2008.

Kanamitsu, M.: Description of the NMC global data assimilation and forecast system, Weather Forecast, 4, 335-342, 1989.

Kanawade, V. P. and Tripathi, S. N.: Evidence for the role of ion-induced particle formation during an atmospheric nucleation event observed in TOPSE, J. Geophys. Res., 111, D02209, doi:10.1029/2005JD006366, 2006.

Kesselmeier, J., Kuhn, U., Rottenberger, S., Biesenthal, T., Wolf, A., Schebeske, G., Andreae, M. O., Ciccioli, P., Brancaleoni, E., Frattoni, M., Oliva, S. T., Botelho, M. L., Silva, C. M. A., and Tavares, T. M.: Concentrations and species composition of atmospheric volatile organic compounds (VOCs) as observed during the wet and dry season in Rondonia (Amazonia), J. Geophys. Res., 107(D20), 8053, doi:10.1029/2000JD000267, 2002.

Kiendler-Scharr, A., Wildt, J., Dal Maso, M., Hohaus, T., Kleist, E., Mente, T. F., Tillmann, R., Uerlings, R., Schurr, U., and Wahner, A.: New particle formation in forests inhibited by isoprene emissions, Nature Lett., 461, 381-384, 2009.

Kim, S., Karl, T., Helmig, D., Daly, R., Rasmussen, R., and Guenther, G.: Measurement of atmospheric sesquiterpenes by proton transfer reation-mass spectrometry (PTR-MS), Atmos. Meas. Tech., 2, 99-112, 2009,

http://www.atmos-meas-tech.net/2/99/2009/.

Kuang, C., McMurry, P. H., McCormick, A. V., and Eisele, F. L.: Dependence of nucleation rates on sulfuric acid vapor concentration in diverse atmospheric locations, J. Geophys. Res., 113, D10209, doi:10.1029/2007JD009253, 2008.

Kulmala, M., dal Maso, M., Makela, J. M., Pirjola, L., Vakeva, M., Aalto, P., Miikkulainen, P., Hameri, K., and O'Dowd, C. D.: On the formation, growth, and composition of nucleation mode particles Tellus 53B, 479-490, 2001.

Kulmala, M., Vehkamaki, H., Petaja, T., dal Maso, M., Lauri, A., Kerminen, V. M., Birmili, W. H., and McMurry, P. H.: Formation and growth rates of ultrafine atmospheric particles: A review of observations, J. Aerosol Sci., 35, 143-176, 2004.
Kunhikrishnan, T., Lawrence, M. G., Kuhlmann, R. V., Richter, A., Ladstätter-WeiXenmayer, A., and Burrows, J. P.: Analysis of tropospheric $\mathrm{NO}_{\mathrm{x}}$ over Asia using the model of atmospheric transport and chemistry (MATCH-MPIC) and GOME-satellite observations, Atmos. Environ., 38, 581-596, 2004.

Laakso, L., Laakso, H., Aalto, P. P., Keronen, P., Petäjä, T., Nieminen, T., Pohja, T., Siivola, E., Kulmala, M., Kgabi, N., Molefe, M., Mabaso, D., Phalatse, D., Pienaar, K., and Kerminen, V.-M.: Basic characteristics of atmospheric particles, trace gases and meteorology in a relatively clean Southern African Savannah environment, Atmos. Chem. Phys., 8, 4823-4839, doi:10.5194/acp-8-4823-2008, 2008.

Larsen, B. R., Di Bella, D., Glasius, M., Winterhalter, R., Jensen, N. R., and Hijorth, J.: Gas-phase $\mathrm{OH}$ oxidation of monoterpenes: Gaseous and particulate products, J. Atmos. Chem., 38, 231-276, 2001.

Lee, S.-H., Reeves, J. M., Wilson, J. C., Hunton, D. E., Viggiano, A. A., Miller, T. M., Ballenthin, J. O., and Lait, L. R.: Particle formation by ion nucleation in the upper troposphere and lower stratosphere, Science, 301, 1886-1889, 2003.

Lelieveld, .J, Butler, T. M., Crowley, J. N., Dillon, T. J., Fischer, H., Ganzeveld, L., Harder, H., Lawrence, M. G., Martinez, M., Taraborrelli, D., and Williams, J.: Atmospheric oxidation capacity sustained by a tropical forest, Nature, 452, 737-740, 2008.

Lindinger, W., Hansel, A., and Jordan, A.: On-line monitoring of volatile organic compounds at pptv levels by means of protontransfer-reaction mass spectrometry (PTRM-MS) - medical applications, food control, and environmental research, Int. J. Mass. Spect, 173, 191-241, 1998.

Lovejoy, E. R., Curtius, J., and Froyd, K. D.: Atmospheric ioninduced nucleation of sulfuric acid and water J. Geophys. Res., 109, D08204, doi:10.1029/2003JD004460, 2004.

Makela, J. M., Alto, P., Jokinen, V., Pohja, T., Nissenin, A., Palmroth, S., Markkanen, T., Seitsonen, K., and Kulmala, M.: Observations of ultrafine aerosol particle formation and growth in boreal forest, Geophys. Res. Lett., 24(10), 1219-1222, doi:10.1029/97GL00920, 1997.

Martin, S. T., Andreae, M. O., Artaxo, P., Baumgardner, D., Chen, Q., Goldstein, A. H., Guenther, A., Heald, C. L., Mayol-Bracero, O. L., McMurry, P. H., Pauliquevis, T., Pöschl, U., Prather, K. A., Roberts, G. C., Saleska, S. R., Silva Dias, M. A., Spracklen, D. V., Swietlicki, E., and Trebs, I.: Sources and properties of Amazonian aerosol particles, Rev. Geophys., 48, RG2002, doi:10.1029/2008RG000280, 2010.

Martinez, M., Harder, H., Kubistin, D., Rudolf, M., Bozem, H., Eerdekens, G., Fischer, H., Klupfel, T., Gurk, C., Konigstedt, R., Parchatka, U., Schiller, C. L., Stickler, A., Williams, J., and Lelieveld, J.: Hydroxyl radicals in the tropical troposphere over the Suriname rainforest: Airborne measurements, Atmos. Chem. Phys., 10, 3759-3773, doi:10.5194/acp-10-3759-2010, 2010.

McMurry, P. H., Fink, M., Sakuri, H., Stolzenburg, M., Mauldin III, R. L., Smith, J., Eisele, F. L., Moore, K., Sjostedt, S., Tanner, D., Huey, L. G., Nowak, J. B., Edgerton, E., and Voisin, D.: A criterion for new particle formation in the sulfur-rich Atlanta atmosphere, J. Geophys. Res., 110, D22S02, doi:10.1029/2005JD005901, 2005.

Merikanto, J., Napari, I., Vehkamäki, H., Anttila, T., and Kulmala, M.: New parameterization of sulfuric acid-ammonia-water ternary nucleation rates at tropospheric conditions, J. Geophys. 
Res., 112, D15207, doi:15210.11029/12006JD007977, 2007.

Metzger, A., Verheggen, B., Dommen, J., Duplissy, J., Prevot, A. S. H., Weingartner, E., Riipinen, I., Kulmala, M., Spracklen, D. V., Carslaw, K. S., and Baltensperger, U.: Evidence for the role of organics in aerosol particle formation under atmospheric conditions, Proc. Natl. Acad. Sci., USA, 107, 6646-6651, 2010.

Mielke, L. H., Pratt, K. A., Shepson, P. B., McLuckey, S. A., Wisthaler, A., and Hansel, A.: Quantitative determination of biogenic volatile organic compounds in the atmosphere using proton-transfer reaction linear ion trap mass spectrometry, Anal. Chem., 82, 7952-7957, 2010.

Modgil, M. S., Kumar, S., Tripathi, S. N., and Lovejoy, E. R.: A parameterization of ion-induced nucleation of sulfuric acid and water for atmospheric conditions J. Geophys. Res., 110, D19205, doi:10.1029/2004JD005475, 2005.

Nowak, J. B., Huey, L. G., Russell, A. G., Tian, D., Neuman, J. A., Orsini, D., Sjostedt, S. J., Sullivan, A. P., Tanner, D. J., Weber, R. J., Nenes, A., Edgerton, E., and Fehsenfeld, F. C.: Analysis of urban gas phase ammonia measurements from the 2002 Atlanta aerosol nucleation and real-time characterization experiment (ANARCHE), J. Geophys. Res., 111, D17308, doi:10.1029/2006JD007113, 2006.

O’Dowd, C. D., AAlto, P., Hameri, K., Kulmala, M., and Hoffmann, M. R.: Atmospheric particles from organic vapors, Nature, 416, 497-498, 2002.

Ortega, J., Helmig, D., Guenther, A., Harley, P., Pressley, S., and Vogel, C.: Flux estimates and oh reaction potential of reactive biogenic volatile organic compounds (BVOCs) from a mixed northern hardwood forest, Atmos. Environ., 41, 54795495, 2007.

Paulot, F., Crounse, J. D., Kiaergaard, J. G., Kurten, A., Clair, J. M. S., Seinfeld, J. H., and Wennberg, P. O.: Unexpected epoxide formation in the gas-phase photooxidation of isoprene, Science, 325, 730-733, 2009.

Pearsall, D. R.: Landscape ecosystems of the University of Michigan biological station: Ecosystem diversity and ground-cover diversity, PhD Thesis, School of Natural Resources and Environment, University of Michigan, USA, 1995.

Petaja, T., Mauldin, R. L., III, Kosciuch, E., McGrath, J., Nieminen, T., Paasonen, P., Boy, M., Adamov, A., Kotiaho, T., and Kulmala, M.: Sulfuric acid and oh concentrations in a boreal forest site, Atmos. Chem. Phys., 9, 7435-7448, doi:10.5194/acp-9-7435-2009, 2009.

Pham, M., Muller, J. F., Brasseur, G., Granier, C., and Megie, G.: A three-dimensional study of the tropospheric sulfur cycle, J. Geohpys. Res., 100(D12), 26061-26092, doi:10.1029/95JD02095, 1995.

Pöschl, U., Martin, S. T., Sinha, B., Chen, Q., Gunthe, S. S., Huffman, J. A., Borrmann, S., Farmer, D. K., Garland, R. M., Helas, G., Jimenez, J. L., King, S. M., Manzi, A., Mikhailov, E., Pauliquevis, T., Petters, M. D., Prenni, A. J., Roldin, P., Rose, D., Schneider, J., Su, H., Zorn, S. R., Artaxo, P., and O., A. M.: Rainforest aerosols as biogenic nuclei of clouds and precipitation in the Amazon, Science, 329, 1513-1516, 2010.

Pressley, S., Lamb, B., Westberg, H., Flaherty, J., Chen, J., and Vogel, C.: Long-term isoprene flux measurements above a northern hardwood forest, J. Geophys. Res., 110, D07301, doi:10.1029/2004JD005523,2005.

Pressley, S., Lamb, B., Westberg, H., and Vogel, C.: Relationships among canopy scale energy fluxes and isoprene flux derived from long-term, seasonal eddy covariance measurements over a hardwood forest, Agr. Forest Meteorol., 136, 188-202, 2006.

Pryor, S. C., Barthelmie, R. J., Sørensen, L. L., McGrath, J. G., Hopke, P., and Petaja, T.: Spatial and vertical extent of nucleation events in the Midwestern USA: Insights from the nucleation in forests (NIFTy) experiment, Atmos. Chem. Phys., 11, 1641-1657, doi:10.5194/acp-11-1641-2011, 2011.

Richter, A., Burrows, J. P., Nues, H., Granier, C., and Niemeijer, U.: Increase in tropospheric nitrogen dioxide over China observed from space, Nature, 437, 129-130, 2005.

Rinne, H. J. I., Guenther, A. B., Greenberg, J. P., and Harley, P. C.: Isoprene and monoterpene fluxes measured above Amazonian rainforest and their dependence on light and temperature, Atmos. Environ., 36, 2421-2426, 2002.

Rizzo, L. V., Artaxo, P., Karl, T., Guenther, A. B., and J., G.: Aerosol properties, in-canopy gradients, turbulent fluxes and VOC concentrations at a pristine forest site in Amazonia, Atmos. Environ., 44, 503-511, 2010.

Rosen, J. M., Hoffmann, D. J., and Gringel, W.: Measurements of ion mobility to $30 \mathrm{~km}$, J. Geophys. Res., 90(D4), 5876-5884, doi:10.1029/JD090iD04p05876, 1985.

Sakulyanontvittaya, T., Duhl, T., Wiedinmyer, C., Helmig, D., Matsunaga, S., Potosnak, M., Milford, J., and Guenther, A.: Monoterpene and sesquiterpene emission estimates for the united states, Environ. Sci. Technol., 42, 1623-1629, 2008.

Schmid, H. P., Su, H.-B., Vogel, C. S., and Curtis, C. S.: Ecosystematmosphere exchange of carbon dioxide over a mixed hardwood forest in northern lower Michigan, J. Geohpys. Res., 108, 4417, doi:10.1029/2002JD003011, 2003.

Sellegri, K., Hanke, M., Umann, B., Arnold, F., and Kulmala, M.: Measurements of organic gases during aerosol formation events in the boreal forest atmosphere during QUEST, Atmos. Chem. Phys., 5, 373-384, doi:10.5194/acp-5-373-2005, 2005.

Sihto, S.-L., Kulmala, M., Kerminen, V.-M., Dal Maso, M., Petäjä, T., Riipinen, I., Korhonen, H., Arnold, F., Janson, R., Boy, M., Laaksonen, A., and Lehtinen, K. E. J.: Atmospheric sulfuric acid and aerosol formation: Implications form atmospheric measurements for nucleation and early growth mechanisms, Atmos. Chem. Phys, 6, 4079-4091, doi:10.5194/acp-6-4079-2006, 2006.

Sipila, M., Berndt, T., Petaja, T., Brus, D., Vanhanen, J., Stratmann, F., Patokoski, J., Mauldin III, R. L., Hyvarinen, A.-P., Lihavainen, H., and Kulmala, M.: The role of sulfuric acid in atmospheric nucleation, Science, 327, 1243-1246, 2010.

Slade, J. H. V., T. M., Mwaniki, G. R., Bertman, S., Stirm, B., and Shepson, P. B.: Aerosol production from the surface of the Great lakes, Geophys. Res. Lett, 37, L18807, doi:10.1029/2010GL043852, 2010.

Smith, J. N., Barsanti, K. C., Friedli, H. R., Ehn, M., Kulmala, M., Collins, D. R., Scheckman, J. H., Williams, B. J., and McMurry, P. H.: Observations of aminium salts in atmospheric nanoparticles and possible climatic implications, Proc. Natl. Acad. Sci., USA, 107, 6634-6639 2009.

Steiner, A. L., Pressley, S. N., Botros, A., Jones, E., Chung, S. H., and Edburg, S. L.: Analysis of coherent structures and atmosphere-canopy coupling strength during the CABINEX field campaign: Implications for atmospheric chemistry, Atmos. Chem. Phys. Discuss., in preparation, 2011. 
Sorooshian, A., Varutbangkul, V., Brechtel, F. J., Ervens, B., Feingold, G., Bahreini, R., Murphy, S. M., Holloway, J. S., Atlas, E. L., Buzorius, G., Jonsson, H., Flagan, R. C., and Seinfeld, J. H.: Oxalic acid in clear and cloudy atmospheres: Analysis of data from International Consortium for Atmospheric Research on Transport and Transformation 2004, J. Geophys. Res., 111, D23S45, doi:10.1029/2005JD006880, 2006.

Spirig, C., Guenther, A., Greenberg, J. P., Calanca, P., and Tarvainen, V.: Tethered balloon measurements of biogenic volatile organic compounds at a boreal forest site, Atmos. Chem. Phys., 4, 215-229, doi:10.5194/acp-4-215-2004, 2004.

Spracklen, D. V., Carslaw, K. S., Kulmala, M., Kerminen, V.-M., Sihto, S.-L., Riipinen, I., Merikanto, J., Mann, G. W., Chipperfield, M. P., Wiedensohler, A., Birmili, W., and Lihavainen, H.: Contribution of particle formation to global cloud condensation nuclei concentrations, Geophys. Res. Lett., 35, L06808, doi:10.1029/2007GL033038, 2008.

Suni, T., Rinne, J., Reissell, A., Altimir, N., Keronen, P., Rannik, U., Dal Maso, M., Kulmala, M., and Vesala, T.: Long-term measurements of surface fluxes above a Scots pine forest in Hyytiala, Southern Finland, 1996-2001, Boreal Environ. Res., 8, 287-301, 2003.

Suni, T., Kulmala, M., Hirsikko, A., Bergman, T., Laakso, L., Aalto, P. P., Leuning, R., Cleugh, H., Zegelin, S., Hughes, D., van Gorsel, E., Kitchen, M., Vana, M., Horrak, U., Mirme, S., Mirme, A., Sevanto, S., Twining, J., and Tadros, C.: Formation and characteristics of ions and charged aerosol particles in a native Australian eucalypt forest, Atmos. Chem. Phys., 8, 129-139, doi:10.5194/acp-8-129-2008, 2008.

Suni, T., Sogacheva, L., Lauros, J., Hakola, H., Bäck, J., Kurtén, T., Cleugh, H., van Gorsel, E., Briggs, P., Sevanto, S., and Kulmala, M.: Cold oceans enhance terrestrial new-particle formation in near-coastal forests, Atmos. Chem. Phys., 9, 8639-8650, doi:10.5194/acp-9-8639-2009, 2009.

Surratt, J. D., Chan, A. W. H., Eddingsaas, H. E., Chan, M., Loza, C. L., Kwan, A. J., Hersey, S. S., Flagan, R. C., Wennberg, P. O., and Seinfeld, J. H.: Reactive intermediates revealed in secondary organic aerosol formation from isoprene, Proc. Natl. Acad. Sci., USA, 107, 6640-6645, 2010.

Tanner, D. J. and Eisele, F. L.: Present oh measurement limits and associated uncertainties, J. Geophys. Res., 100(D2), 4622, doi:10.1029/94JD02609, 1995.
Tunved, P., Hansson, H.-C., Kerminen, V.-M., Ström, J., Dal Maso, M., Lihavainen, H., Viisanen, Y., Aalto, P. P., Komppula, M., and Kulmala, M.: High natural aerosol loading over boreal forests, Science, 312, 261-263, 2006.

Vehkamäki, H., Kulmala, M., Napari, I., Lehtinen, E. J., Timmreck, C., Noppel, M., and Laaksonen, A.: An improved parameterization for sulfuric acid-water nucleation rates for tropospheric and stratospheric conditions, J. Geophys. Res., 107, 24347-24358, doi:4610.1029/2002JD002184, 2002.

Westberg, H., Lamb, B., Hafer, R., Hills, A., Shepson, P. B., and Vogel, C.: Measurement of isoprene fluxes at the PROPHET site, J. Geophys. Res., 106(D20), 24347-24358, doi:10.1029/2000JD900735, 2001.

Young, L. H., Benson, D. R., Kameel, F. R., Pierce, J. R., Junninen, H., Kulmala, M., and Lee, S.-H.: Laboratory studies of $\mathrm{H}_{2} \mathrm{SO}_{4} / \mathrm{H}_{2} \mathrm{O}$ binary homogeneous nucleation from the $\mathrm{SO}_{2}+\mathrm{OH}$ reaction: evaluation of the experimental setup and preliminary results, Atmos. Chem. Phys., 8, 4997-5016, doi:10.5194/acp-84997-2008, 2008.

Yu, F. and Turco, R. P.: The role of ions in the formation and evolution of particles in aircraft plumes, Geophys. Res. Lett, 24(15), 1927-1930, doi:10.1029/97GL01822, 1997.

Yu, J., Cocker III, D. R., Griffin, R. J., Flagan, R. C., and Seinfeld, J. H.: Gas-phase ozone oxidation of monoterpenes: Gaseous and particulate products, J. Atmos. Chem., 34, 207-258, 1999.

Zhang, R., Suh, J., Zhao, J., Zhang, D., Fortner, E. C., Tie, X., Molina, M. T., and Molina, M., J.: Atmospheric new particle formation enhanced by organic acids, Science, 304, 1487-1490, 2004.

Zhang, R., Wang, L., Khalizov, A. F., Zhao, J., Zheng, J., McGraw, R. L., and Molina, L. T.: Formation of nanoparticles of blue haze enhanced by anthropogenic pollution, Proc. Natl. Acad. Sci. USA, 106, 17560-17654, 2009.

Zhou, J. C., Swietlicki, E., Hansson, H. C., and Artaxo, P.: Submicrometer aerosol particle size distribution and hygroscopic growth measured in the Amazon rain forest during the wet season, J. Geophys. Res., 107, 8055, doi:10.1029/2000JD000203, 2002. 